Article

\title{
Evaluation of Non-Conventional Biological and Molecular Parameters as Potential Indicators of Quality and Functionality of Urban Biosolids Used as Organic Amendments of Agricultural Soils
}

\author{
Miriam del Rocío Medina-Herrera ${ }^{1}$, María de la Luz Xochilt Negrete-Rodríguez ${ }^{1,2}$, \\ José Luis Álvarez-Trejo ${ }^{3}$, Midory Samaniego-Hernández ${ }^{2}$, Leopoldo González-Cruz ${ }^{1}$ (D) \\ Aurea Bernardino-Nicanor ${ }^{1}$ (D) and Eloy Conde-Barajas $1,2, * \mathbb{D}$ \\ 1 Department of Biochemical Engineering of Tecnológico Nacional de México/IT de Celaya, \\ Celaya 38010, Guanajuato, Mexico; ibqmmedina@gmail.com (M.d.R.M.-H.); \\ xochilt.negrete@itcelaya.edu.mx (M.d.1.L.X.N.-R.); leopoldo.gonzalez@itcelaya.edu.mx (L.G.-C.); \\ aurea.bernardino@itcelaya.edu.mx (A.B.-N.) \\ 2 Department of Environmental Engineering, Tecnológico Nacional de México/IT de Celaya, \\ Celaya 38010, Guanajuato, Mexico; midory.samaniego@itcelaya.edu.mx \\ 3 Management of Administrative and Operation of the Wastewater Treatment Plant (WWTP) of Celaya, \\ Ecosistema de Celaya S.A. de C.V., Celaya 38037, Guanajuato, Mexico; jalvarez@ticsa.com.mx \\ * Correspondence: eloy.conde@itcelaya.edu.mx; Tel.: +52-46-1611-7575
}

Received: 18 November 2019; Accepted: 7 January 2020; Published: 10 January 2020

\begin{abstract}
Biosolids are waste from wastewater treatment and have a high content of organic matter and nutrients. In this study, not conventional physicochemical and biological properties of biosolids produced during different seasons of the year were evaluated. These properties are not considered in environmental regulations; however, they are of agronomic interest as indicators of quality and functionality in soils. Also, molecular analysis by Fourier-transform infrared (FTIR) was conducted, enzymatic analysis using the APIZYM ${ }^{\circledR}$ system was performed and two indices of functional and microbial diversity were established. The results showed that the biosolids had a high content of total organic carbon, total nitrogen, P, and K. FTIR analyses showed that chemical composition of biosolids was similar during all year. The $\mathrm{C}$ and $\mathrm{N}$ of microbial biomass demonstrated presence of active microorganisms, as well as a uniformity in its richness and abundance of species that could present a positive synergy with soil microorganisms. The enzymatic activities showed that the biosolids contained an enzymatic machinery available to promote the mineralisation of the organic matter of biosolids and could even transcend into the soil. Finally, biological properties can be used as indicators of quality and functionality of biosolids before being used as an organic amendment, especially in agricultural soils.
\end{abstract}

Keywords: biosolids; quality index; microbial biomass; enzymatic activity; micro and macronutrients; organic amendment

\section{Introduction}

Waste sludge is a waste product that originated in the wastewater treatment process. Wastewater treatment consists of a series of physical, chemical, and biological processes that have the purpose of eliminating the contaminants present in the water $[1,2]$. The wastewater treatment process usually has three stages (primary, secondary, and tertiary). The first stage aims to remove large solids (garbage), sand and suspended solids from the affluent, through a system of sieves or screems, sandblasting and 
sedimentation $[1,3]$. The sludge generated at this stage named primary sludge is hazardous waste and is sent to confinement [2]. The second stage of wastewater treatment aims to eliminate dissolved organic matter present in wastewater [1-3]. This stage is carried out mainly through processes of a biological nature that have in common the use of microorganisms to remove biodegradable organic matter [4]. The third stage of wastewater treatment aims to remove the residual organic load and those persistent pollutants not removed in previous treatments, e.g., $\mathrm{N}$ and $\mathrm{P}[3,5]$. The sludge generated in the secondary and tertiary stages of wastewater treatment is combined and sent to stabilisation processes [5]. These sludges are known as residual sludges and are characterized by a high content of easily degradable organic matter and nutrients, which can be used as soil improvers and even fertilizers for crops. However, due to the nature of their origin, they also contain germs, viruses, and pathogenic parasites that must be eliminated prior to use [3,5]. Therefore, the sludge is subjected to stabilisation processes to eliminate contaminants.

The sludge stabilisation processes can be biological, chemical, and thermal. Biological methods include aerobic and anaerobic digestion and composting [6,7]. The most commonly used chemical method is lime stabilisation [8-10]. The thermal stabilisation processes used are pyrolysis, burns or complete incineration $[7,9]$. Due to efficiency and costs, the most common process is biological stabilisation, which can be performed under anaerobic (fermentation) and aerobic (oxidative stabilisation) conditions [9,11]. Aerobic digestion, which is of interest in this study, involves the use of the process of decomposition of organic matter contained in sludge through microbial activity under aerobic conditions [4,9]. The organic matter in the sludge is a substrate for the three-phase microbial metabolic chain [9]. In the first phase, easily degradable organic matter is oxidized by interaction of enzymes produced by microorganisms that live in the activated sludge, resulting in rapid multiplication of microorganisms [4]. Microorganisms use organic matter to increase their biomass and synthesis of enzymes this occurs until easily degradable organic matter is depleted [2,9]. In the second phase, after the depletion of organic matter, the cellular material is oxidized, and the microorganisms obtain energy from the self-oxidation of these cellular substances [3,9]. In the third phase, further intracellular oxidation is continued. Phases two and three are called aerobic stability $[2,3,9]$. The stabilized residual sludges are called biosolids and can be used as soil improvers and fertilizers as long as they comply with the established regulations $[1,3,9]$.

The generation of biosolids during urban effluent treatment has increased in Mexico, as there has been an increase in the number of urban wastewater treatment plants (UWWTPs). By 2016, the National Water Commission (CONAGUA) registered 2536 wastewater treatment plants in operation [10]. This represented an increase in the flow of treated wastewater of $25,946.58 \mathrm{~L} / \mathrm{s}$. As a result, the amount of biosolids generated throughout the country increased at the same rate. Therefore, there is a need to develop strategies for the management, use, and final disposal of biosolids with a minimum impact on society and the environment. Both nationally and internationally, it has been necessary to recycle and reduce the amount of biosolids sent to landfills, avoiding saturation [11]. In the same context, incineration and application to sanitary landfills and incineration and application to soils have been the main forms of final disposal of biosolids [12]. However, the disposal of biosolids in landfills or by incineration are technologies in which these biosolids rich in organic matter $(\mathrm{OM})$ and nutrients are not used for crops or plants [13]. In addition, most incineration technologies release hazardous chemicals such as dioxins, furans, $\mathrm{NOx}, \mathrm{SO}_{2}$, and hydrocarbons into the atmosphere [14]. The application of biosolids to soils provides a source of nutrients available to plants because biosolids have been reported to contain valuable amounts of stable organic matter, providing long-term benefits for soil structure and fertility [15]. However, biosolids also need to be evaluated from different points of view-for example, in the aspect of their characterisation over time from their generation source (UWWTP). The variability of the $\mathrm{C}$ and $\mathrm{N}$ content, as well as of the micro and macro nutrients in the biosolids before their application to the soils, should be evaluated. Also, the safety of biosolids and the cumulative effects of various physicochemical and biological parameters over time need to be considered in the assessment. 
In the same context, biosolids contain pathogens, parasites, heavy metals, and xenobiotic organic compounds that can cause health and environmental damage [16-20]. There are regulatory standards at the national [21] and international level [22,23] for the application of biosolids to both agricultural and forest soils (Table 1), which include the control of parasites (Helminth), pathogens (total coliforms and Salmonella sp.), and heavy metals ( $\mathrm{As}, \mathrm{Cd}, \mathrm{Cu}, \mathrm{Cr}, \mathrm{Hg}, \mathrm{Ni}, \mathrm{Pb}$, and $\mathrm{Zn}$ ), principally. However, there are no regulatory standards regarding the speed of application of biosolids to agricultural soils. In the same context, there are also not many studies evaluating the variability over time of their properties or of biological and molecular parameters only in biosolids. These properties and parameters have been evaluated to monitor the effects of the application of biosolids to soils over time but have not been evaluated to be used as indicators of quality and functionality of a substrate per se (e.g., biosolids) as an improved in agricultural soils. These evaluations include the following: analysis of functional groups by FTIR, microbial biomass $C$ and $N(M B C$ and $M B N)$, biochemical relationships $\left(\mathrm{C}_{\text {mic }} / \mathrm{N}_{\text {mic }}\right)$, metabolic coefficients or microbial activity ( $\left.\mathrm{qCO}_{2}, \mathrm{qFDA}\right)$, enzymatic activities that relate the cycles of $\mathrm{C}, \mathrm{N}$ and $\mathrm{P}$, such as lipases, esterases and proteases (FDA); dehydrogenases (DHS), the proportion of DHS and FDA, urease activity (URS) and the production of respiration $\left(\mathrm{CO}_{2}\right)$. Also included are enzyme activity monitoring systems that allow the establishment of "fingerprints" or activity enzyme "profiles" such as the API ZYM ${ }^{\circledR}$ system. As well, the establishment of indices of functional diversity and microbial activity, such as the Shannon index $\left(H^{\prime}\right)$ and synthetic enzymatic index (SEI) is also important for their potential contribution as indicators of quality and agronomic functionality of biosolids before and after being applied as soil improvers [24-40]. Only U.S.A. regulation stipulates that the agronomic speed of application cannot be exceeded [41]; to protect the quality of groundwater or surface water, nitrogen must be regulated through an agronomic rate approach, which requires an estimate of the need for $\mathrm{N}$ from the crop and the availability of $\mathrm{N}$ in biosolids [41,42].

In context, there is unfortunately no reliable parameter as an adequate indicator of the stability and maturity of biosolids used as organic amendments in soils. However, some biochemical parameters, such as microbial biomass and enzymatic activities, are useful indicators of ecosystem quality and functionality $[26,28]$. Microbial biomass represents the living part of an ecosystem and is responsible for the transformation of organic matter, therefore the importance of assessing its status in biosolids [24]. The microorganisms have a set of enzymes both intracellular (e.g., dehydrogenases) and extracellular (hydrolytic enzymes such as glucosidase, esterases, proteases, etc.) responsible for the breakdown of organic matter, nitrogen transformations and can provide information on the biological status of biosolids. Hydrolytic activity of extracellular enzymes has received attention for several reasons: (1) these activities play a key role in the hydrolysis and mineralisation of organic wastes; (2) the characterisation of enzyme activities can provide insight into the biochemical factors controlling nutrient mineralisation; and (3) patterns of enzyme activities can be useful in identifying microbial populations [43]. Several enzyme assays are available to determine the hydrolytic activity in different environmental matrices. One of these enzymatic assays is the API ZYM ${ }^{\circledR}$ system which has been used in environmental matrices with complex biochemical processes e.g., soils, compost, activated sludge and sediments $[34-39,44]$. This system provides rapid and semi-quantitative information on the hydrolytic activity of 19 enzymes associated with the biodegradation of lipids, proteins, carbohydrates, and nucleic acids $[34,36,39]$. Therefore, the importance of monitoring a wide range of enzymes involved in various biochemical processes such as those occurring in biosolids is emphasized. It is also proposed to monitor these enzymes to establish the possible effects before adding them to the soil in order to establish a better management of these biosolids as organic amendments in agricultural soils. Derived from the above, the following hypothesis was proposed: biosolids, regardless of the time they are generated in a stabilized wastewater treatment process, possess physicochemical and/or biological properties or characteristics of agronomic interest that can be used for their application as soil improvers. Finally, the present study evaluated, over time, the conventional physicochemical parameters of agricultural interest, as well as the biological and molecular parameters of agronomic interest, but not those contemplated in the regulations, of urban biosolids from a UWWTP. It also 
aimed to establish technical-scientific arguments in the use of these non-standardised biological and molecular parameters as indicators of quality and functionality of the biosolids used as soil improvers. The biological and molecular results obtained could be considered as indicators of functionality when establishing application rates in agricultural soils. The results obtained also aim to contribute to the correct management, recovery and use of this type of waste generated in a WWTP, regardless of the time of year in which they are generated.

Table 1. Regulatory standards for the application of biosolids in soils established in national and international standards.

\begin{tabular}{ccccc}
\hline \multirow{2}{*}{ Parameter } & Value * & \multicolumn{3}{c}{ MPL of Contaminants in Biosolids } \\
\cline { 3 - 5 } & & Mexico & EE. UU. & E.U. \\
\hline Fecal coliforms $\left(\mathrm{MPN} \mathrm{g}^{-1}\right)$ & 210,000 & $<2,000,000$ & $<2,000,000$ & N.R. \\
Salmonella sp. $\left(\mathrm{MPN} \mathrm{g}^{-1}\right)$ & $<3$ & $<300$ & $<4$ & N.R. \\
Helminth Eggs $\left(\mathrm{eggs} \mathrm{g}^{-1}\right)$ & $<1$ & $<35$ & $<1$ & N.R. \\
As $\left(\mathrm{mg} \mathrm{kg}^{-1}\right)$ & 1.81 & 75 & 41 & N.R. \\
$\mathrm{Cd}\left(\mathrm{mg} \mathrm{kg}^{-1}\right)$ & 7.41 & 85 & 39 & $20-40$ \\
$\mathrm{Cu}\left(\mathrm{mg} \mathrm{kg}^{-1}\right)$ & 107.28 & 4300 & 1500 & $1000-1750$ \\
$\mathrm{Cr}\left(\mathrm{mg} \mathrm{kg}^{-1}\right)$ & 28.46 & 3000 & N.R. & N.R. \\
$\mathrm{Hg}\left(\mathrm{mg} \mathrm{kg}^{-1}\right)$ & 1.03 & 840 & 17 & $16-25$ \\
$\mathrm{Ni}\left(\mathrm{mg} \mathrm{kg}^{-1}\right)$ & 30.19 & 57 & 420 & $300-400$ \\
$\mathrm{~Pb}\left(\mathrm{mg} \mathrm{kg}^{-1}\right)$ & 38.19 & 420 & 300 & $750-1200$ \\
$\mathrm{Zn}\left(\mathrm{mg} \mathrm{kg}^{-1}\right)$ & 707.95 & 7500 & 2800 & $2500-4000$ \\
\hline
\end{tabular}

* The results are reported on a dry basis and are the average of the data obtained in the half-yearly analyses carried out by UWTP of Celaya from 2014 to December 2018. MPL = Maximum permissible limit; EE. UU. = United States; E.U. = European Union; N.R. = Not regulated. MPL data were obtained for Mexico from NOM-004-SEMARNAT-2002, for the United States from EPA Standard 40CFR- 503 and for the European Union from 86/278/EEC [21-23].

\section{Materials and Methods}

\subsection{Production, Sampling and Status of Biosolids}

The biosolids were sampled monthly during 2018 at a UWWTP in Guanajuato, Mexico, located at geographic coordinates $100^{\circ} 51^{\prime} 64^{\prime \prime} \mathrm{W}$ and $20^{\circ} 30^{\prime} 78^{\prime \prime} \mathrm{N}$ (Figure 1). The biosolids were produced by biological treatments and aerobic digestion processes. After the aerobic digestion process, the produced solids were dehydrated by means of pressed band filtration systems. The biosolids were taken six times over a four-hour period on the conveyor belt at the outlet of the filter press. Approximately $30 \mathrm{~kg}$ in total of the sample on a wet basis $(85 \%)$ were collected during each sampling performed [21]. The samples were taken at random in triplicate from day 7 to day 23 of each month, for 1 year, with a total of 36 samples. The samples were taken to the laboratory, dried in the air, sieved through a $2 \mathrm{~mm}$ diameter mesh and stored at $4{ }^{\circ} \mathrm{C}$ for further analysis. The analysis of their physicochemical and biological properties did not exceed the storage time of 1 week $[45,46]$.

As an antecedent, the biosolids produced in this study have been evaluated from August 2014 to December 2018 (three times a year randomly), complying with the physicochemical standards established in current national and international regulations [21-23,41] for their correct final disposal. These standards only include the content of pathogens, parasites, and heavy metals in biosolids produced in a UWWTP. The biosolids have been below the permissible limits both nationally and internationally for their use (Table 1). Therefore, biosolids before this study were applied to agricultural soils but without characterisations under other parameters that are potentially applicable as biological and molecular indicators of agronomic interest or fertility for soils. 

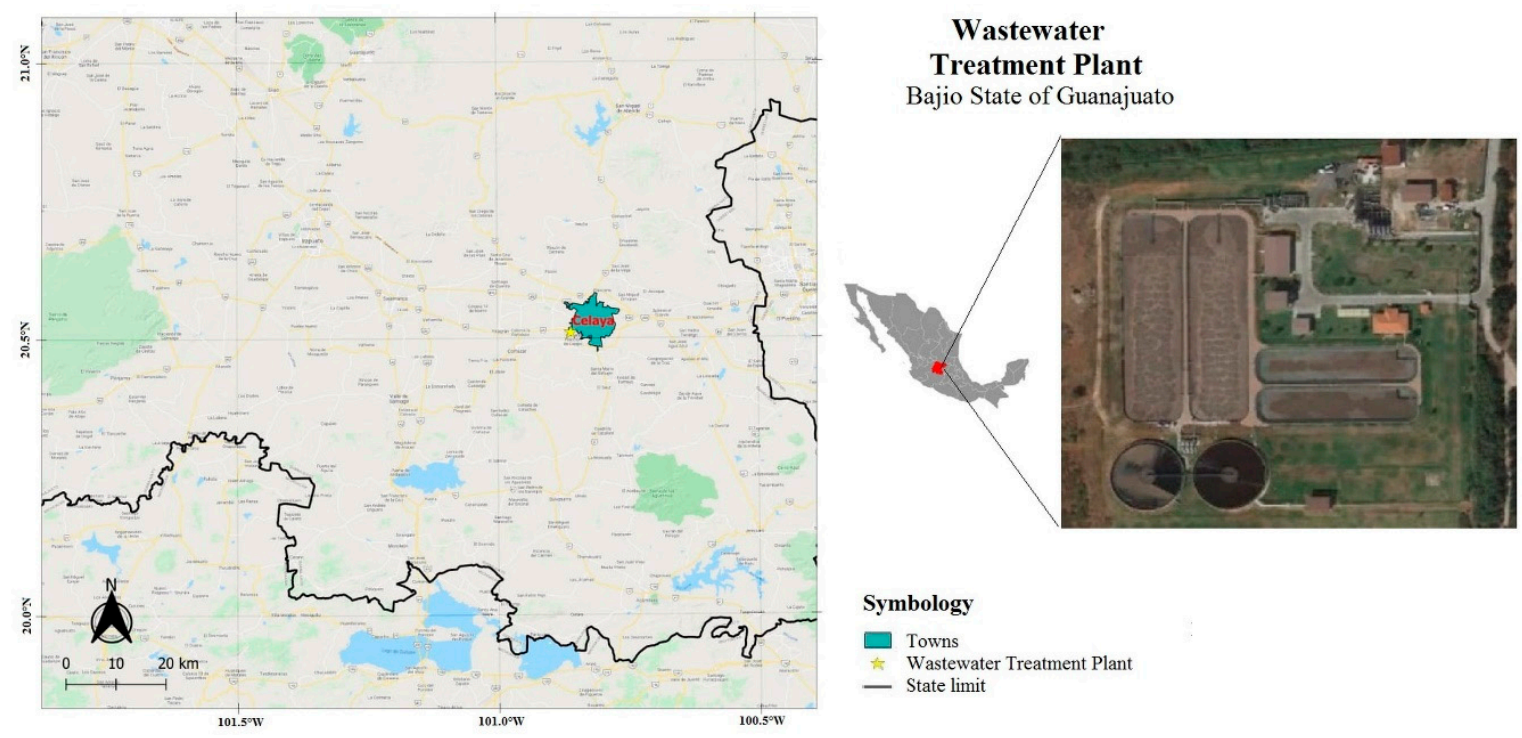

Figure 1. Location map of the urban wastewater treatment plant of the municipality of Celaya, Guanajuato, Mexico with geographical coordinates $100^{\circ} 51^{\prime} 64^{\prime \prime} \mathrm{W}$ and $20^{\circ} 30^{\prime} 78^{\prime \prime} \mathrm{N}$.

\subsection{Physicochemical Characterisation of Biosolids and Obtaining FTIR Spectra}

The characterisation of the biosolids was carried out every month, for 1 year. The $\mathrm{pH}$ and electrical conductivity (EC) were measured in a mixture of biosolids and deionised water, at a ratio of 1:2.5 and 1:5 (m:v), respectively $[45,47,48]$. Total organic carbon (TOC) was determined by oxidation with potassium dichromate according to the Walkley and Black method [49], modified by downscaling and colorimetric determination [50]. Total nitrogen (TN) was analysed by micro-Kjeldhal system [51]. With the TOC and TN values, the $\mathrm{C} / \mathrm{N}$ ratios were obtained. Macro and micronutrients $(\mathrm{P}, \mathrm{K}, \mathrm{Fe}, \mathrm{B}, \mathrm{Mn}, \mathrm{Zn}$, and $\mathrm{Cu}$ ) were determined by microwave digestion with the EPA3051A/2007 method [52]. Briefly, the digested samples were cooled to room temperature, filtered (Watman paper 41), and measured at $50 \mathrm{~mL}$ with distilled water [53]. The content of each element was determined by inductively coupled plasma atomic emission spectrometry (ICP-AES), which was calibrated with a target and 5 standards [54].

For molecular analyses using Fourier transform infrared spectra (FTIR), samples of approximately $2 \mathrm{~g}$ of ground and sieved biosolids $(<0.5 \mathrm{~mm})$ were placed in an oven at $105^{\circ} \mathrm{C}$ for $24 \mathrm{~h}$. A subsample of $5 \mathrm{mg}$ (dry basis) was mixed with $500 \mathrm{mg}$ of $\mathrm{KBr}$, crushed and homogenised in an agate mortar to form a fine powder. A translucent $\mathrm{KBr}$ tablet was formed from a press. The FTIR absorbance spectra of the biosolids were determined by scanning the tablets at a wave number range of 4000 to $400 \mathrm{~cm}^{-1}$ with a resolution of 8 using a FTIR Spectrometer. The main functional groups detected in biosolids were identified by comparison with Johnston and Aochi [29] and Martínez et al. [33].

\subsection{Biological Characterisation and Enzymatic Profile of Biosolids}

For the characterisation of biological parameters not considered in the standards of regulation the $\mathrm{C}$ and $\mathrm{N}$ of the microbial biomass (MBC and $\mathrm{MBN}$ ) was determined by the fumigation method extraction at $25{ }^{\circ} \mathrm{C}$ [55]. With the values of $\mathrm{MBC}$ and $\mathrm{MBN}$, the $\mathrm{C}_{\text {mic }} / \mathrm{N}_{\text {mic }}$ ratio was calculated.

The enzyme activity of dehydrogenase (DHS) was determined according to Von Mersi and Schinner [28]. The microbial and enzymatic activity of families of lipases, esters and proteases were evaluated by hydrolysis of fluorescein diacetate (FDA) using the method established by Green et al. [32]. The DHS/FDA ratio was calculated with the values obtained for the DSH and FDA enzymatic activities, respectively [56]. The enzymatic activity of urease (URS) was determined according to Kandeler and Gerber [25].

Basal respiration was determined by $\mathrm{C}-\mathrm{CO}_{2}$ produced after 20 days of incubation at $25{ }^{\circ} \mathrm{C}$, as reported by Anderson [57]. The metabolic coefficient $\left(\mathrm{qCO}_{2}\right)$ was estimated by the quotient of 
microbial basal respiration (C- $\left.\mathrm{CO}_{2}\right)$ and MBC [27]. Specific hydrolytic activity (qFDA) was calculated by dividing the FDA activity value and MBC content as established by Perucci et al. [30].

To evaluate the enzymatic profiles in the biosolids studied during 1 year, the API ZYM ${ }^{\circledR}$ system was used, consisting of sterile galleries with 20 domes for control and 19 hydrolytic enzymes, including 3 phosphatases (alkaline phosphatase, acid phosphatase, Naphthol-AS-BI-phosphohydrolase), 3 esterases (lipase, esterase-lipase, esterase), 3 aminopeptidases (leucine arylamidase, valine arylamidase, cystine arylamidase), 2 proteases (trypsin and $\alpha$-chemotrypsin) and 8 glycosyl hydrolases ( $\alpha$-galactosidase, $\beta$-galactosidase, $\beta$-glucuronidase, $\alpha$-glucosidase, $\beta$-glucosidase, $N$-acetyl- $\beta$-glucosaminidase, $\alpha$-mannosidase, $\alpha$-fucosidase). The activity of these hydrolytic enzymes in biosolids was determined according to the manufacturer's instructions (BioMérieux), by means of aqueous extracts, in triplicate [58]. The aqueous extracts were prepared from a mixture of biosolid:distilled water $(1: 3, \mathrm{~m} / \mathrm{v})$, stirred for $20 \mathrm{~min}$ at $25^{\circ} \mathrm{C}$ and centrifuged at $2000 \mathrm{rpm}$ for $10 \mathrm{~min}$ as established by Tiquia et al. [34]. The supernatant was filtered and used for enzymatic analysis. In each dome, $65 \mu \mathrm{L}$ of the supernatant was distributed, the chamber was covered and incubated at $37^{\circ} \mathrm{C}$ for $4 \mathrm{~h}$ [58]. After incubation, $30 \mu \mathrm{L}$ of each ZYM A and ZYM B reagent were added to each dome and allowed to stand for $5 \mathrm{~min}$ to reveal the colour change in the substrates. After this time, the enzyme activity intensity reading was taken by assigning numerical values from 0 to 5 to each reaction according to the manufacturer's reading table and reported in the literature $[34,36,37]$. Colour intensity readings for enzymatic reactions were performed by 4 independent observers [38]. With the results obtained, an extracellular enzyme profile diagram was designed as established by Patel et al. [39]. The diagram is obtained by classifying the enzymes in the 5 families (phosphatase, esterase/lipase, amino peptidase, protease and glucosyl hydrolases) and their intensity was placed according to the following scale: (1) high activity for enzymes with intensity number obtained according to the manufacturer reading; (2) moderate activity for enzymes with intensity numbers between 2 and 3; (3) low activity for enzymes with intensity number 1; and (4) activity not detected for enzymes with intensity number 0 . Subsequently, all the enzymes that showed activity $\geq 1, \geq 2, \geq 4$ and $=0$ are added. Thus, the state of the hydrolytic activities of the enzymes were evaluated by API ZYM ${ }^{\circledR}$.

In addition, the Shannon index was determined to assess the status of the microbial community in biosolids based on their distribution and diversity using Equation (1) [59].

$$
H^{\prime}=-\sum p_{i} \ln p_{i}
$$

where $p i$ is the relationship of the activity of an enzyme to total enzyme activity. On the other hand, biochemical functional diversity or total enzyme activity was expressed by a synthetic enzyme index (SEI) that was calculated as reported by Dumontet et al. [31]. The SEI was evaluated as the sum of the colour intensity developed later in the enzymatic reactions translated into terms of amount of hydrolysed substrate, where 0 is $0 \mathrm{nmol}$ of hydrolysed substrate, 1 is 5,2 is 10,3 is 20, 4 is 30 and 5 is $\geq 40 \mathrm{nmol}$ hydrolysed substrate, respectively [35].

\subsection{Statistical Analysis}

Statistical analysis of the results obtained in physicochemical and biological characterisation was performed using the statistical analysis software, Minitab v. 18 [60]. The statistical significance of the differences between the parameter means was carried out by means of an ANOVA followed by a Tukey test $(p \leq 0.05)$. To calculate the general correlation between physicochemical and biological parameters, the Pearson product-moment correlation was used [39].

\section{Results and Discussion}

As an introduction to the results obtained, it is important to emphasize that sustainable management of biosolids requires that special attention be paid to the rate and type of biosolids most 
appropriate for the level of soil fertility required, in order to minimize the risk of eutrophication and maximize the benefits for soil ecosystem services [61-63].

\subsection{Physicochemical Characterisation of Biosolids}

The physicochemical characteristics of the biosolids at different times of the year are presented in Table 2. The $\mathrm{pH}$ values obtained ranged between 6.10 and 6.41 , so they were considered slightly acidic. These $\mathrm{pH}$ values were not significantly different $(\mathrm{F}=0.237, p=0.869)$ from each other. The tendency to present a slight acidity may be due to the presence of organic acids derived from the degradation of organic matter present in wastewater. In other studies, in which biosolids have been generated from urban wastewater treatment and used for organic amendments, $\mathrm{pH}$ values have been reported in a range of 5.5 to 6.5 [13,63], similar to those obtained in this study. Torres et al. [64] established that the slightly acidic $\mathrm{pH}$ of organic amendments (e.g., biosolids) can be attributed to mineralisation processes of organic matter due to the presence of labile organic compounds available for microbial metabolism. These compounds may be aliphatic organic acids, amino acids and their polymeric derivatives (e.g., proteins and polypeptides), polysaccharides, lipids and other low molecular weight organic compounds. Thus, the slightly acidic $\mathrm{pH}$ of the evaluated biosolids may be related to the chemical composition of the organic matter present in the biosolids and their mineralisation. The EC in biosolids evaluated at different times of the year showed significant differences $(\mathrm{F}=8.43, p=0.007)$ (Table 2). Values between 1.60 and $5.71 \mathrm{dS} \mathrm{m}^{-1}$ were observed, which implied an important salt content, characteristic of biosolids from urban wastewater treatment $[65,66]$. The highest value was presented in spring $\left(5.71 \mathrm{dS} \mathrm{m}^{-1}\right)$ and the lowest in autumn $\left(1.60 \mathrm{dS} \mathrm{m}^{-1}\right)$. However, the EC values obtained were within the range of those reported in the literature $\left(0.90\right.$ to $\left.12.5 \mathrm{dS} \mathrm{m}^{-1}\right)$ for biosolids generated during urban wastewater treatment of aerobic and anaerobic processes [67-69]. Studies on the application of biosolids and their effect on soil physicochemical properties have reported an increase in EC values, including as a function of the application rates used [19,70-72]. On the other hand, Lloret et al. [72] evaluated the effect of the application of biosolids coming from aerobic and anaerobic treatments on the chemical and biological properties of the soil. The evaluated soil presented an EC value of $0.48 \mathrm{dS} \mathrm{m}^{-1}$. After the application of the aerobic and anaerobic biosolids, the EC in the soil increased to 2.0 and $2.8 \mathrm{dS} \mathrm{m}^{-1}$, respectively, and these values were maintained for the 2 months that the experiment lasted. With this information, the EC and its variation in biosolids generated in urban wastewater treatment plants, both in aerobic and anaerobic processes, should be monitored over time [21,61], as well as before and after being applied to agricultural soils, to prevent possible salt accumulations causing salinity or salinity-sodicity problems in soils [73].

Under the same context, the benefit of applying biosolids as organic amendments to agricultural soils lies in the presence of labile organic matter, which can constitute an energy reserve in the soil [74]. Therefore, for a better use of biosolids, it is important to know the total organic carbon content (TOC) and its variation over time before its application to agricultural soils. TOC varied in the biosolids sampled at different times of the year in an interval of 36.90 to $57.94 \%$ (Table 2). The highest TOC value was in summer $(57.94 \%)$ and the lowest was in winter $(36.90 \%)$. The TOC values obtained at different times of the year were significantly different $(\mathrm{F}=55.655, p=0.000)$ from each other. With respect to TOC values in biosolids and sewage sludge reported in the literature, these are lower than those obtained in the present study. Rowell et al. [75], for the purpose of soil application, evaluated different biosolids from different UWWTP as a result of both aerobic and anaerobic wastewater treatment and digestion processes. The values obtained were lower than those obtained in this study ranging in a TOC range from 31.80 to $35.10 \%$. In similar studies of different types of biosolids from aerobic digestion processes and activated sludge or anaerobic digestion systems, the average TOC values reported were below those obtained in this study $[11,68]$. Thus, the biosolids analysed in this study, despite their variability in TOC content, probably due to the biochemical composition of wastewater, wastewater treatments and sludge stabilisation processes, presented a high $C$ content. It is then argued that the biosolids in this study can be used as potential sources of labile or affordable sources of $C$, for application in agricultural 
soils or with fertility problems. However, due to their variability, the need to monitor the TOC content of biosolids produced in the WWTPs over time, especially before and after their application to agricultural soils, is highlighted. The above is needed for a better design or application plan (dosage) and does not only consider the total amount of biosolids (Ton $\mathrm{Ha}^{-1}$ ), as is currently practiced at the local or regional level. In addition, due to the variability of TOC presented in the evaluated biosolids, it is important to establish short- and long-term studies on its effects on $\mathrm{C}$ mineralisation rates $\left(\mathrm{CO}_{2}\right.$ emissions), incorporation into microbial biomass (MBC), enzymatic activities, and global $\mathrm{C}$ balances (inputs and outputs) when applied to soils. Biosolids have been characterised as an organic residue rich in nitrogen [19]. The TN content of the biosolids analysed at different times of the year ranged between $6.35 \%$ and $6.78 \%$, with no significant differences ( $\mathrm{F}=0.200, p=0.893$ ) between them. From the values obtained, it was considered that the evaluated TN is a stable parameter regardless of the time of year in which it is analysed. In function to the non-variability in the $\mathrm{N}$ content observed in the evaluated biosolids, this parameter could then be used as an indicator or criterion of quality and functionality during the design of agronomic doses or application rates to agricultural soils or soils with $\mathrm{N}$ deficiencies. However, the values obtained were high (1.54 to $4.07 \%)$ compared to those reported in other studies where biosolids have been characterised for organic amendments to agricultural soils $[11,18,75]$. In the same context, the effect of applying biosolids to soils makes the $\mathrm{N}$ content increase and is also available to crops longer, especially when the organic $\mathrm{N}$ content is mineralised (nitrification) to inorganic forms, mainly $\mathrm{N}^{-\mathrm{NH}_{4}}{ }^{+}$and $\mathrm{N}-\mathrm{NO}_{3}{ }^{-}[68,76,77]$. Thus, a physicochemical indicator of functionality or quality of biosolids to consider, which is linked to biological processes of $\mathrm{N}$ mineralisation, can be, not only the $\mathrm{N}$ content in soil and $\mathrm{N}$ requirements in crops, but also the $\mathrm{N}$ content in biosolids, especially during the design of soil application dosages $[19,78]$.

The content of $\mathrm{C}$ and $\mathrm{N}$ in biosolids are 2 parameters of interest during the application of organic amendment to soils. Although the $\mathrm{C}$ and $\mathrm{N}$ content in the analysed biosolids was high compared to the values reported in the literature, the $\mathrm{C} / \mathrm{N}$ ratio was within the previously reported values $[18,68]$. The $\mathrm{C} / \mathrm{N}$ ratio of biosolids ranged from 5.64 to 8.64 for different times of the year and were statistically different $(\mathrm{F}=10.243, p=0.004)$. The highest $\mathrm{C} / \mathrm{N}$ ratio was presented in summer $(8.64)$ and the lowest in spring (5.64). These results are within the range of 4.4 to 22.0 obtained for the $\mathrm{C} / \mathrm{N}$ ratio of biosolids analysed in other studies $[13,45,66]$. Hseu and Huang [79], evaluated the mineralisation of $\mathrm{N}$ in 2 biosolids, 1 anaerobic and 1 aerobic, with a $\mathrm{C} / \mathrm{N}$ ratio of 6.7 and 4.7, respectively, establishing that the $\mathrm{C} / \mathrm{N}$ ratio is an important factor to evaluate in the mineralisation processes of biosolids in agricultural soils. Flores-Marguez et al. [67] conducted a study of biosolids mineralisation in agricultural soils and established that the $\mathrm{C} / \mathrm{N}$ ratio was inversely related to the mineralisation rate of $\mathrm{C}$ and $\mathrm{N}$. These results coincide with Brady and Weil [80] "organic amendments with low $\mathrm{C} / \mathrm{N}$ ratio decompose more rapidly, once incorporated into the soil, than those with a high $\mathrm{C} / \mathrm{N}$ ratio (>25). Matos et al. [11], established that low rates of $C$ mineralisation in soils are potentially related to high $\mathrm{C} / \mathrm{N}$ ratios $(>30)$ and organic matter stability. Therefore, biosolids with an average $\mathrm{C} / \mathrm{N}$ of 6.94 can conserve the $\mathrm{C} / \mathrm{N}$ of the soil-biosolids system, without affecting $C$ mineralisation rates by avoiding organic matter losses in the soil. One of the advantages of using biosolids as organic amendments is that they contain nutrients other than $\mathrm{N}$, such as $\mathrm{P}$ and $\mathrm{K}$, as well as micronutrients [81]. The content of $\mathrm{P}$ and $\mathrm{K}$ in the analysed biosolids was from 1.48 to $2.65 \%$ and from 0.59 to $1.09 \%$, respectively. The content of $\mathrm{P}$ and $\mathrm{K}$ was significantly different $(\mathrm{F}=51.778, p=0.000$ and $\mathrm{F}=28.732, p=0.001$, respectively) between the seasons of the year. In spring, the highest $\mathrm{P}$ and $\mathrm{K}$ contents were presented, at 2.65 and $1.09 \%$, respectively. The lowest value for $\mathrm{P}$ was $1.48 \%$ and corresponds to summer, while for $\mathrm{K}$ it was $0.59 \%$ in autumn. The results obtained from $\mathrm{P}$ and $\mathrm{K}$ in the evaluated biosolids were higher than those obtained by Paramashivam et al. [13], who reported $\mathrm{P}$ and $\mathrm{K}$ values for aerobic biosolids of 0.14 and $0.46 \%$, respectively. Lü et al. [81] established that for different biosolids (aerobic, anaerobic and digested), the N, P and K content ranged from 2 to $8 \%, 1.5$ to $3 \%$, and 0.1 to $0.6 \%$, respectively. The $\mathrm{N}$ and $\mathrm{P}$ content of the biosolids evaluated in this study were within the reported range; however, $\mathrm{K}$ was above that reported in other studies [81-83]. In addition, it is important to establish the amount of nutrients provided by biosolids as they are added 
to the soil, because although biosolids are a source of nutrients (N, P and K), they often do not replace the use of commercial fertilisers, since their content of N, P and $\mathrm{K}$ may be less than that required for crops. Zhang et al. [84] conducted a long-term field experiment (4 years) with 3 doses of biosolids applied to the soil and found that it was necessary to add chemical fertilisers of $\mathrm{P}$ and $\mathrm{K}$ to cover the growth needs of the crops. However, the P released (organic P to inorganic P) from the biosolids increased in the soil depending on the application rate of the biosolids.

Table 2. Physicochemical characteristics and nutrient content in biosolids collected and evaluated in the urban wastewater treatment plant (UWWTP) at different season of year.

\begin{tabular}{ccccc}
\hline \multirow{2}{*}{ Parameters } & \multicolumn{4}{c}{ Biosolids Analysed for Each Season of the Year } \\
\cline { 2 - 5 } & Spring & Summer & Autumn & Winter \\
\hline $\mathrm{pH}$ & $6.10 \pm 0.17 \mathrm{a}$ & $6.20 \pm 0.40 \mathrm{a}$ & $6.17 \pm 0.17 \mathrm{a}$ & $6.41 \pm 0.83 \mathrm{a}$ \\
$\mathrm{EC}\left(\mathrm{dS} \mathrm{m}{ }^{-1}\right)$ & $5.71 \pm 1.93 \mathrm{a}$ & $3.38 \pm 1.25 \mathrm{a}, \mathrm{b}$ & $1.60 \pm 0.01 \mathrm{~b}$ & $1.65 \pm 0.18 \mathrm{~b}$ \\
$\mathrm{TOC}(\%)$ & $37.25 \pm 4.37 \mathrm{c}$ & $57.94 \pm 1.25 \mathrm{a}$ & $50.25 \pm 0.96 \mathrm{~b}$ & $36.90 \pm 1.17 \mathrm{c}$ \\
$\mathrm{TN}(\%)$ & $6.67 \pm 0.98 \mathrm{a}$ & $6.78 \pm 0.82 \mathrm{a}$ & $6.59 \pm 0.47 \mathrm{a}$ & $6.35 \pm 0.42 \mathrm{a}$ \\
$\mathrm{C} / \mathrm{N}$ & $5.64 \pm 0.78 \mathrm{~b}$ & $8.64 \pm 1.18 \mathrm{a}$ & $7.65 \pm 0.56 \mathrm{a}, \mathrm{b}$ & $5.83 \pm 1.38 \mathrm{~b}$ \\
$\mathrm{P}(\%)$ & $2.65 \pm 0.17 \mathrm{a}$ & $1.48 \pm 0.14 \mathrm{~b}$ & $1.76 \pm 0.03 \mathrm{~b}$ & $2.28 \pm 0.13 \mathrm{a}$ \\
$\mathrm{K}(\%)$ & $1.09 \pm 0.12 \mathrm{a}$ & $0.69 \pm 0.07 \mathrm{~b}, \mathrm{c}$ & $0.59 \pm 0.03 \mathrm{c}$ & $0.86 \pm 0.04 \mathrm{~b}$ \\
$\mathrm{Fe}\left(\mathrm{g} \mathrm{kg}^{-1}\right)^{\mathrm{T}}$ & $16.10 \pm 0.40 \mathrm{c}$ & $39.28 \pm 1.77 \mathrm{a}$ & $20.43 \pm 0.59 \mathrm{~b}$ & $17.34 \pm 1.91 \mathrm{c}$ \\
$\mathrm{B}\left(\mathrm{mg} \mathrm{kg}^{-1}\right)^{\mathrm{T}}$ & $143.33 \pm 12.01 \mathrm{~b}$ & $145.00 \pm 8.00 \mathrm{~b}$ & $172.62 \pm 2.13 \mathrm{a}$ & $122.41 \pm 8.41 \mathrm{~b}$ \\
$\mathrm{Mn}\left(\mathrm{mg} \mathrm{kg}^{-1}\right)^{\mathrm{T}}$ & $130.00 \pm 8.00 \mathrm{c}$ & $215.62 \pm 7.39 \mathrm{a}$ & $166.30 \pm 4.59 \mathrm{~b}$ & $126.85 \pm 7.56 \mathrm{c}$ \\
$\mathrm{Zn}\left(\mathrm{mg} \mathrm{kg}^{-1}\right)^{\mathrm{T}}$ & $778.67 \pm 13.50 \mathrm{~b}$ & $635.65 \pm 10.55 \mathrm{c}$ & $602.76 \pm 2.34 \mathrm{~d}$ & $813.51 \pm 10.58 \mathrm{~b}$ \\
$\mathrm{Cu}\left(\mathrm{mg} \mathrm{kg}^{-1}\right)^{\mathrm{T}}$ & $133.64 \pm 12.01 \mathrm{a}$ & $112.39 \pm 5.56 \mathrm{~b}$ & $95.22 \pm 2.84 \mathrm{~b}$ & $132.42 \pm 5.64 \mathrm{a}$ \\
\hline
\end{tabular}

$\mathrm{EC}=$ Electrical conductivity, $\mathrm{TOC}=$ Total organic carbon and $\mathrm{C} / \mathrm{N}=$ carbon-nitrogen ratio. The values are the mean \pm standard deviation ( 3 replicates). Rows with different letters are significantly different according to Tukey's analysis with $p \leq 0.05 .{ }^{\top}$ The units correspond to biosolids on a dry basis.

Similarly, studies have reported that the content of $\mathrm{K}$ in biosolids ( 0.1 to $0.6 \%)$ is generally very small [82-85]. The low K content in biosolids significantly increases the nutrient imbalance in terms of the N:P:K ratio, so the most common practice is to add $\mathrm{K}$ fertilisers independently of biosolids when necessary [85]. However, the biosolids analysed in this work presented a content of 0.59 to $1.09 \% \mathrm{~K}$, being above the commonly reported value for biosolids; however, they cannot be considered high without analysing the $\mathrm{K}$ content in the soil and the $\mathrm{K}$ requirements depending on the type of crop. Therefore, the importance of knowing the content of these macronutrients in biosolids is reiterated, in order to avoid adverse environmental effects or low crop yields.

The micronutrients present in the biosolids studied were Fe (16.10 to $39.28 \mathrm{~g} \mathrm{~kg}^{-1}$ dry biosolids), B (122.41 to $172.62 \mathrm{mg} \mathrm{kg}^{-1}$ dry biosolids), Mn (126.85 to $215.62 \mathrm{mg} \mathrm{kg}^{-1}$ dry biosolids), $\mathrm{Zn}$ (602.76 to $813.51 \mathrm{mg} \mathrm{kg}^{-1}$ dry biosolids), and $\mathrm{Cu}$ (95.22 to $132.42 \mathrm{mg} \mathrm{kg}^{-1}$ dry biosolids). These results are similar to some previous studies of different biosolids that have reported the presence of micronutrients [86-88]. From the above, the results established in the literature is confirmed in the sense that biosolids not only contribute organic matter to soils, but also macro and micronutrients that can be used by crops. However, the results obtained from all micronutrients in the evaluated biosolids were significantly different $(\mathrm{Fe}, \mathrm{F}=314.456, p=0.000 ; \mathrm{B}, \mathrm{F}=22.683, p=0.002 ; \mathrm{Mn}, \mathrm{F}=144.483, p=0.000 ; \mathrm{Zn}, \mathrm{F}=405.291$, $p=0.000 ; \mathrm{Cu}, \mathrm{F}=21.570, p=0.003$ ) at different seasons of the year. Confirming the importance of analysing the amount of each of these micronutrients present in biosolids and their evolution over time at the site that has been generated (e.g., UWWTP), as well as after being incorporated depending on the dose of application to the soil. In addition, the quantity of each of these elements required in the soil, as well as in the crops, must also be considered, taking into account the needs of each species to be cultivated in order to maintain a balance of micronutrients suitable both for the soil and for the plants. 


\subsection{Characteristics of the FTIR Spectrum of Biosolids}

Fourier Transform Infrared Spectrometry (FTIR) was used to identify functional groups present in biosolids. The FTIR spectra for biosolids evaluated at different times of the year were very similar to that shown in Figure 2. The bands observed between 3400 and $3500 \mathrm{~cm}^{-1}$ were attributed to O-H stretching of hydroxyl groups in carboxylic groups, phenols, polysaccharides, and saturated aliphatic species [89,90]. In addition, aliphatic methylene groups between 2850 and $2930 \mathrm{~cm}^{-1}$ were detected in all biosolids samples, mainly related to fats and lipids [33,91,92]. Bands found between 1650 and $1750 \mathrm{~cm}^{-1}$, due to $\mathrm{C}=\mathrm{O}$ stretching vibrations, indicated the presence of ketones, aldehydes, and carboxylic acid derivatives in biosolids [81,93]. On the other hand, the $1650 \mathrm{~cm}^{-1}$ band was attributed to $\mathrm{C}-\mathrm{N}$ stretching vibrations in the primary amides of proteins $[33,90,91]$. The presence of primary amides in the evaluated biosolids is confirmed by the presence of bands between 1630 and $1640 \mathrm{~cm}^{-1}$, which corresponds to bending vibrations of $\mathrm{N}-\mathrm{H}[92,94]$. In addition, the absorption bands found that between 1540 and $1560 \mathrm{~cm}^{-1}$ were attributed to secondary amide bonds of protein origin that probably came from human cells present in biosolids [91,95]. Reflection spectral of bands observed that between 1430 and $1450 \mathrm{~cm}^{-1}$ indicated the presence of aliphatic chains, possibly hemicellulose and lignin, due to stretching and bending vibrations $\mathrm{C}-\mathrm{H}$ in $\mathrm{CH}_{2} / \mathrm{CH}_{3}[90,93]$. Likewise, the bands found that between 1440 and $1450 \mathrm{~cm}^{-1}$ have been attributed to aromatic compounds due to stretching vibrations $\mathrm{C}=\mathrm{C}$, mainly related to aromatic components of humic acids $[81,96]$. In addition, a characteristic band at $1434 \mathrm{~cm}^{-1}$ has been reported for aldehydes and ketones due to composting vibrations $C=O$, as a result of the presence of humic and fulvic acids in the stabilisation process of biosolids organic matter because of UWWTP secondary digestion treatments [92]. The bands found that between 1380 and $1400 \mathrm{~cm}^{-1}$ were attributed to symmetrical $\mathrm{COO}$ stretching and $\mathrm{CH}_{3}$ bending vibrations, related to proteins and lipids [93,95]. Likewise, bands observed between 1230 and $1250 \mathrm{~cm}^{-1}$ were associated with tertiary amines due to $\mathrm{C}-\mathrm{N}$ stretching and $\mathrm{N}-\mathrm{H}$ bending vibrations [90], as well as antisymmetric $\mathrm{PO}_{2}$ stretching vibrations related to compounds with phosphodiester bonds, such as phospholipids and nucleic acids: RNA (ribonucleic acid) and DNA (desoxyribonucleic acid) [94]. Finally, absorbance bands between 875 and $1050 \mathrm{~cm}^{-1}$ corresponded to $\mathrm{C}-\mathrm{O}$ and $\mathrm{C}-\mathrm{C}$ stretching vibrations caused by polysaccharides and aromatic compounds [81,92]. Overall, the band-reflection spectra obtained by FTIR from the evaluated biosolids were like the results reported in the literature on biosolids and sewage sludge [90-93]. In fact, these molecular analyses showed a similar chemical composition in all the biosolids analysed in the different seasons of the year, presenting mostly the same absorbance bands. Therefore, it was possible to mention that the evaluated biosolids presented the same functional groups indicating that the chemical compounds present in the different seasons of the year were very similar and of low variability.

With respect to the changes in the "absorbance intensity" of the bands identified in the FTIR reflection spectra, these changes were not significant (see Figure 3; A, F =1.427, $p=0.304 ; \mathrm{B}, \mathrm{F}=0.999$, $p=0.441 ; \mathrm{C}, \mathrm{F}=2.846, p=0.106 ; \mathrm{D}, \mathrm{F}=5.023, p=0.030 ; \mathrm{E}, \mathrm{F}=2.217, p=0.122 ; \mathrm{F}, \mathrm{F}=0.013, p=0.998$; $\mathrm{G}, \mathrm{F}=0.859, p=0.500 ; \mathrm{H}, \mathrm{F}=1.589, p=0.267 ; \mathrm{I}, \mathrm{F}=0.751, p=0.552$ ) between seasons of the year. It was then determined that the "functional groups" identified for each of the analysed bands were similar in all biosolids samples, regardless of the time of year. This may be due to the fact that the wastewater treated throughout the year has the same origin and the UWWTP wastewater treatment process has been stable, without significant modifications at least during the study period of the biosolids generated. It could also be inferred that during the evaluation period, the handling of sewage sludge and its stabilisation process to be transformed into biosolids was stable. 

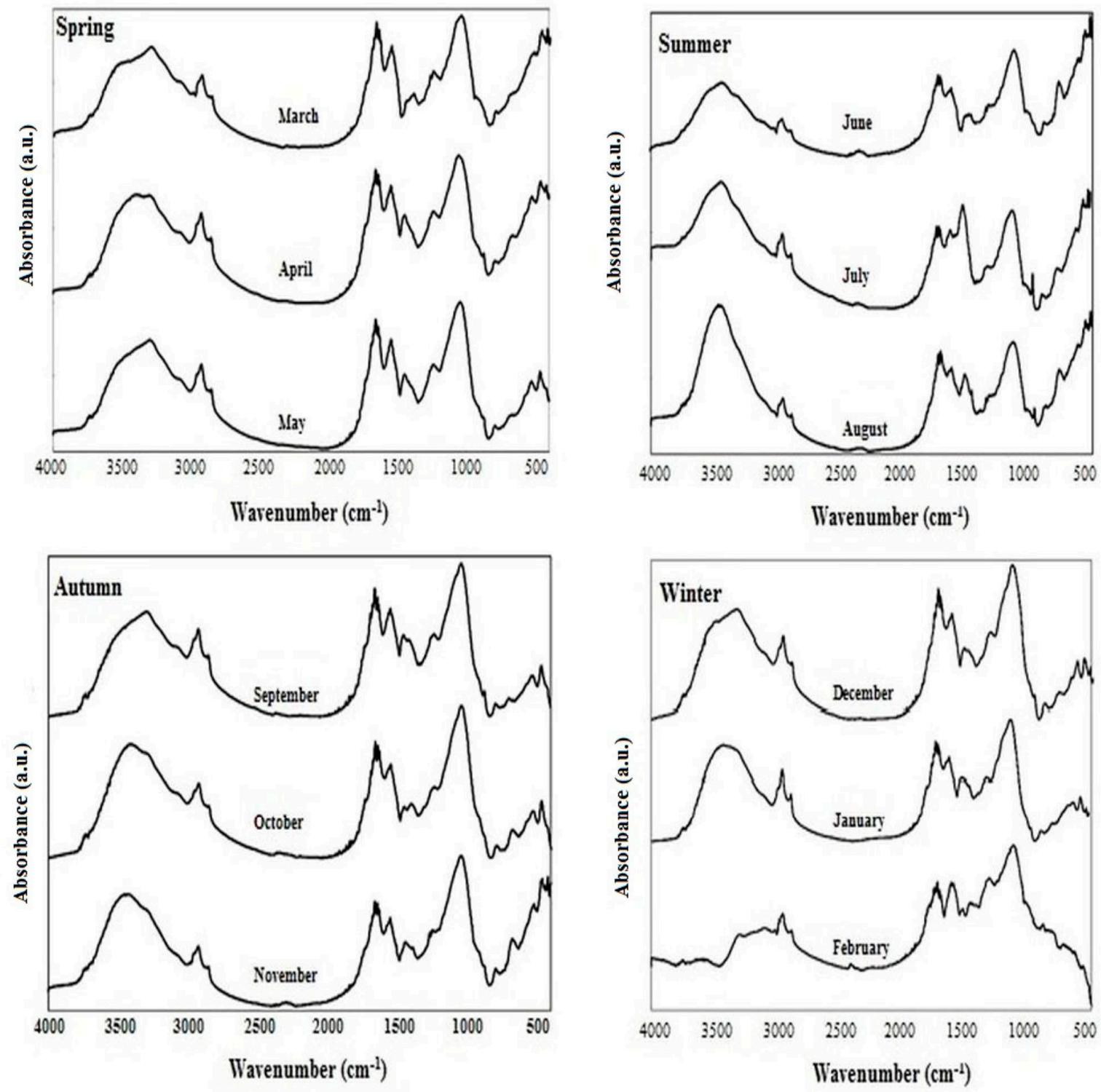

Figure 2. FTIR spectra of biosolids collected and evaluated in the UWWTP during different season of the year.

With the information obtained from the analysis of the absorption bands of the main functional groups evaluated in biosolids of the different seasons of the year, the presence of easily biodegradable molecules was established: carboxylic acids, proteins, lipids and aliphatic hydrocarbons, as well as recalcitrant or hardly biodegradable molecules (e.g., hemicellulose, cellulose and lignin). Therefore, establishing a "biostability indicator" related to the biodegradability of these biosolids is difficult without evaluating biological aspects related to the mineralisation processes of biosolids, such as microbial and enzymatic activity, and their relationship with the chemical composition of biosolids. Lü et al. [81], mentioned that microbial activity is directly associated with the content of bioavailable organic matter, and therefore, this parameter is relevant to being widely included during the evaluation of the "biostability" of organic residues such as biosolids. Thus, microbial activity reflected in enzyme activity may be directly related to the presence of some compounds in biosolids, e.g., lipases with lipids, proteases and aminopeptidases with peptides and proteins, phosphatases with phospholipids and nucleic acids, hydrolases glycosylated with aliphatic compounds, polysaccharides, etc. For this reason, it is important to evaluate biological characteristics not included in the sanitary regulations applicable to biosolids before and after their application to soils, especially to soils with agricultural activity. 


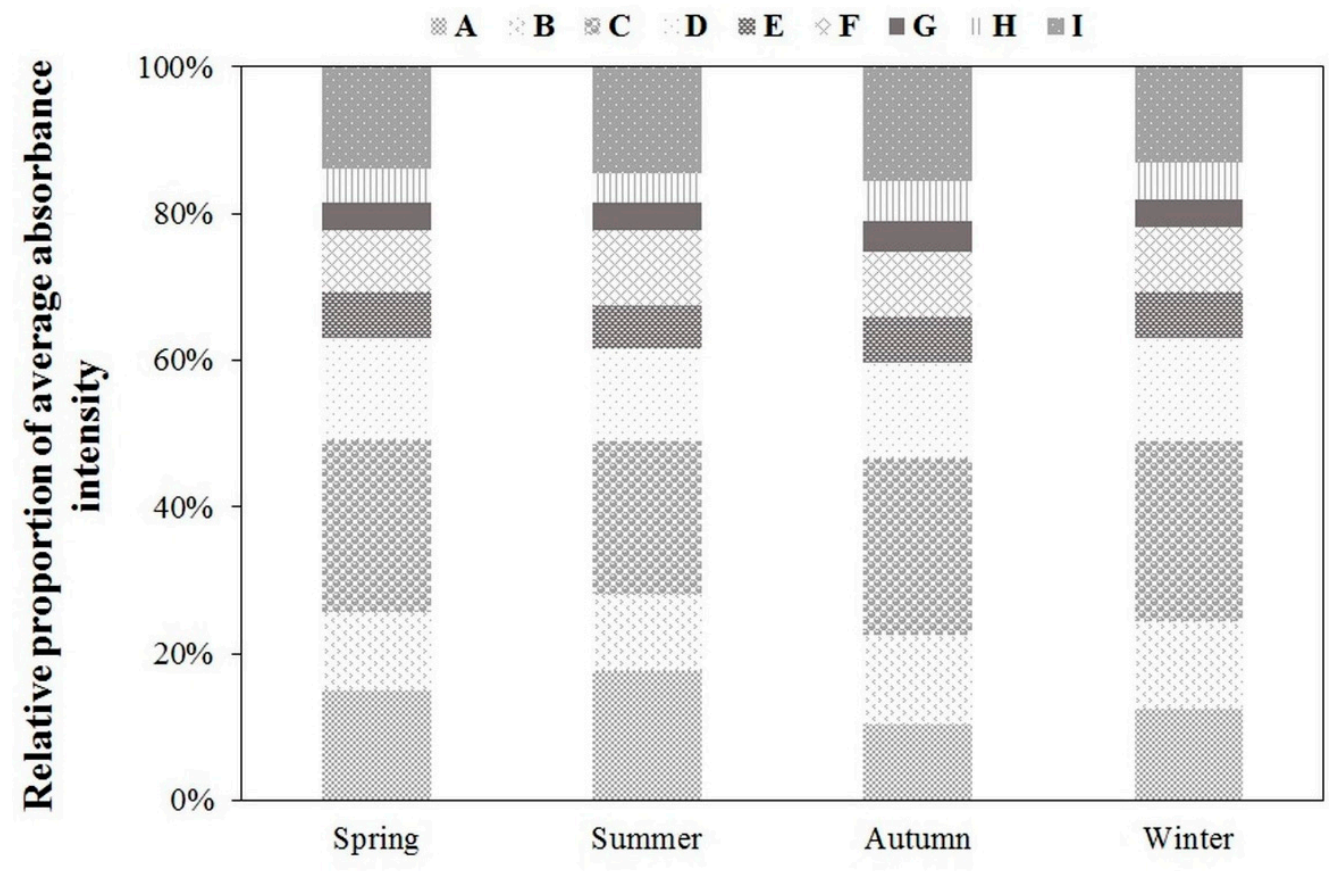

\section{Season of the year}

Figure 3. Distribution of absorbance intensity for each set of peaks found in the FTIR analysis of biosolids samples for each season of the year. Each box in the bars represents the absorbance peaks ordered according to wavelength: (A) $3400-3500 \mathrm{~cm}^{-1}$, (B) $2850-2930 \mathrm{~cm}^{-1}$, (C) $1650-1750 \mathrm{~cm}^{-1}$, (D) $1630-1650 \mathrm{~cm}^{-1}$, (E) $1540-1550 \mathrm{~cm}^{-1}$, (F) $1430-1450 \mathrm{~cm}^{-1}$, (G) $1380-1400 \mathrm{~cm}^{-1}$, (H) $1230-1250 \mathrm{~cm}^{-1}$ and (I) $875-1050 \mathrm{~cm}^{-1}$.

\subsection{Biological Characterisation of Biosolids}

Biostability is a key feature in biosolids to evaluate their use as organic amendment in soils. In the last decade, studies in soils with various organic amendments have focused on using biological properties for their sensitivity to change, as indicators of the dynamics of organic matter transformation, nutrient cycling, stress and regeneration processes [66,97-99]. Therefore, it was important to evaluate biological parameters for 1 year to establish indicators of quality and functionality of biosolids that have been added to soils, and thus be able to elucidate the positive or negative effects of adding these biosolids to soils before their application.

The biological parameters evaluated in the biosolids obtained in the UWWTP can be found in Table 3. Microbial biomass (MB), defined as the living microbial component of an ecosystem [26], is the primary terrestrial ecosystem agent responsible for decomposition of organic matter, nutrient cycling and energy flow [100,101]. In addition, the MB is considered an important ecological parameter in environmental ecosystems, because it represents the amount of energy stored by microorganisms $[102,103]$. Through the establishment of MB in biosolids and by carefully interpreting their values, it is possible to evaluate and monitor the functionality and quality of biosolids as an organic amendment, and thus predict their effects on soil microbial activity and their relationship with productivity, fertility and resistance to degradation forces. In this case, the BM in biosolids was determined by 3 parameters: $C$ for microbial biomass (MBC), $N$ for microbial biomass (MBN) and the relationship between $\mathrm{C}$ and microbial $\mathrm{N}\left(\mathrm{C}_{\mathrm{mic}} / \mathrm{N}_{\text {mic }}\right)$. These biological parameters were selected because they have been widely used in previous studies of agricultural soils with application of biosolids as organic amendment because they are considered as sensitive and rapid indicators of restoration or ecological stress of the soil or environmental system investigated $[63,104,105]$. The MBC and MBN are the most labile $C$ and $N$ stores in soils $[106,107]$, so their values are likely to be altered quickly in the event of any disturbance in the ecosystem. In addition, MBC and MBN are general 
indices of microbial activity in soils [102,107]. Different soil management practices such as the addition of biosolids greatly affect the MBC and MBN in the soil [108]. For this reason, in order to understand the effect on soils of the application of biosolids, it is necessary to know the values of MBC and MBN in the biosolids before they are added to the soil. The results obtained from MBC in biosolids for different times of the year ranged between 587.22 and $1251.95 \mathrm{mg} \mathrm{C}_{\text {mic }} \mathrm{kg}^{-1}$ dry biosolids. These results were significantly different $(\mathrm{F}=26.318, p=0.000)$ between seasons of the year (Table 3$)$. In winter the lowest MBC content was presented ( $587.22 \mathrm{mg} \mathrm{C}_{\mathrm{mic}} \mathrm{kg}^{-1}$ dry biosolid) and the highest content was in summer (1251.95 $\mathrm{mg} \mathrm{C}_{\text {mic }} \mathrm{kg}^{-1}$ dry biosolid). The previous $\mathrm{MBC}$ values represented a range of 0.16 to $0.26 \%$ of the TOC present in biosolids for the different seasons of the year. However, these values are considerably lower than those established for soils where MBC corresponded to 1 to $3 \%$ of TOC $[94,96]$. The values obtained for MBC in biosolids at different times of the year were higher than those obtained in other agricultural soil studies with addition of biosolids where MBC values ranged from 20.1 to $820 \mathrm{mg} \mathrm{C} \mathrm{kg}^{-1}$ dry soil $[107,109]$. Debosz et al. [109] observed that the application of biosolids to the soil presented a significant increase in MBC from the first 7 days to 60 days of application, and then a decrease to stabilize, so they considered the effect to be temporary. In addition, Fernandes et al. [108] found that MBC presented important variations at different application doses of biosolids to the soil, being directly proportional the increase of $\mathrm{MBC}$ with the application dose. However, none of these studies evaluated the MBC content of biosolids before they were added; therefore, with the results obtained in this study and as stipulated in the literature, it can be established that biosolids provide active microorganisms and affordable organic matter that could have a "positive synergy" with active soil microorganisms. This was stated in this study since in previous studies of application of biosolids to soils a biostimulation of soil $\mathrm{MBC}$ has been observed when using biosolids as an organic amendment.

Table 3. Biological characteristics in biosolids collected and evaluated in the UWWTP at different season of the year.

\begin{tabular}{|c|c|c|c|c|}
\hline \multirow{2}{*}{ Parameters } & \multicolumn{4}{|c|}{ Biosolids Analysed for Each Season of the Year } \\
\hline & Spring & Summer & Autumn & Winter \\
\hline $\operatorname{MBC}\left(\mathrm{mg} \mathrm{C}_{\text {mic }} \mathrm{kg}^{-1}\right)^{\mathrm{T}}$ & $966.6 \pm 46.4 b$ & $1251.9 \pm 134 \mathrm{a}$ & $1149 \pm 115 \mathrm{a}, \mathrm{b}$ & $587.2 \pm 76.7 \mathrm{c}$ \\
\hline $\operatorname{MBN}\left(\mathrm{mg} \mathrm{N}_{\mathrm{mic}} \mathrm{kg}^{-1}\right)^{\mathrm{T}}$ & $84.25 \pm 10.6 b$ & $109.3 \pm 1.4 \mathrm{~b}$ & $304.7 \pm 32.9 \mathrm{a}$ & $119.0 \pm 20.1 \mathrm{~b}$ \\
\hline $\mathrm{C}_{\text {mic }} / \mathrm{N}_{\text {mic }}$ & $11.66 \pm 2.09 \mathrm{a}$ & $11.46 \pm 1.32 \mathrm{a}$ & $3.82 \pm 0.77 \mathrm{~b}$ & $5.07 \pm 1.32 \mathrm{~b}$ \\
\hline $\mathrm{DSH}\left(\mathrm{mg} I N F{ }^{*} \mathrm{~kg}^{-1} \mathrm{~h}^{-1}\right)^{\mathrm{T}}$ & $2631.8 \pm 147 \mathrm{a}$ & $2209.5 \pm 119 a$ & $2426.1 \pm 230 \mathrm{a}$ & $2277.6 \pm 225 a$ \\
\hline $\operatorname{FDA}\left(\mathrm{mg} \mathrm{F}^{* *} \mathrm{~kg}^{-1} \mathrm{~h}^{-1}\right)^{\mathrm{T}}$ & $342.7 \pm 40.0 \mathrm{~b}$ & $279.7 \pm 30.0 \mathrm{~b}$ & $437.96 \pm 44.2 \mathrm{a}$ & $368.6 \pm 24 a, b$ \\
\hline $\mathrm{DSH} / \mathrm{FDA}\left(\mathrm{mg}\right.$ INF $\left.\mathrm{mg}^{-1} \mathrm{~F}^{*}\right)$ & $7.78 \pm 1.35 \mathrm{a}$ & $7.99 \pm 1.26 \mathrm{a}$ & $5.55 \pm 0.22 \mathrm{a}$ & $6.21 \pm 0.84 \mathrm{a}$ \\
\hline URS $\left(m g \text { N-NH }{ }_{4}^{+} \mathrm{kg}^{-1} \mathrm{~h}^{-1}\right)^{\mathrm{T}}$ & $186.0 \pm 17.1 \mathrm{a}$ & $194.5 \pm 23.0 \mathrm{a}$ & $109.8 \pm 7.7 \mathrm{~b}$ & $186.5 \pm 13.7 \mathrm{a}$ \\
\hline $\mathrm{qCO}_{2}\left(\mathrm{mg} \mathrm{C}-\mathrm{CO}_{2} \mathrm{~g}^{-1} \mathrm{C}_{\mathrm{mic}} \mathrm{d}^{-1}\right)$ & $157.95 \pm 7.40 \mathrm{~b}$ & $124.31 \pm 13.5 b$ & $115.42 \pm 11.6 \mathrm{~b}$ & $270.19 \pm 32.9 \mathrm{a}$ \\
\hline qFDA $\left(\mathrm{mg} \mathrm{F}^{* *} \mathrm{~g}^{-1} \mathrm{C}_{\mathrm{mic}} \mathrm{h}^{-1}\right)$ & $356.27 \pm 56.7 b$ & $223.27 \pm 4.84 b$ & $381.57 \pm 26.9 b$ & $636.39 \pm 106 \mathrm{a}$ \\
\hline
\end{tabular}

The results are the mean \pm standard deviation (3 replicates). Rows with different letters are significantly different according to Tukey's analysis with $p \leq 0.05$. T' The units correspond to biosolids on a dry basis. ${ }^{*} \mathrm{INF}=$ Iodonitrotetrazolium formazan (1-(4-Iodophenyl)-5-(4-nitrophenyl)-3 phenyl formazan). ${ }^{* *} \mathrm{~F}=$ Fluorescein.

In the same context, the results obtained for MBN in the evaluated biosolids ranged between 84.25 and $304.70 \mathrm{mg} \mathrm{N}_{\text {mic }} \mathrm{kg}^{-1}$ dry biosolids, exhibiting very significant differences $(\mathrm{F}=240.960, p=0.000)$ between autumn biosolids compared to the biosolids of the rest of the year (Table 3). A content of MBN was observed that corresponded to a range of 0.13 to $0.46 \%$ of the NT present in biosolids for different times of the year. MBN in soils constitutes more than 5\% of NT [107]. The MBN of biosolids was found to be below that reported in soils. The results reported in the literature for MBN of soil with added biosolids have ranged from 3.1 to $101 \mathrm{mg} \mathrm{N}_{\text {mic }} \mathrm{kg}^{-1}$ dry soil [107-109]. However, based on previous studies [108,109], as with MBC, an increase in MBN would be expected with the addition of biosolids to soils. Masunga et al. [110] established that MBN in agricultural ecosystems controls the availability and loss of inorganic $\mathrm{N}$ from the soil, especially in systems with high $\mathrm{N}$ inputs such as agriculture. Therefore, adding an organic amendment, such as biosolids, with active microbial biomass (MBC and 
MBN) can affect natural soil processes, such as the mineralisation of $\mathrm{C}$ and $\mathrm{N}$ as a consequence of a change in microbial structure $[65,111]$. For this reason, it is important to evaluate both MBC and MBN in soils and biosolids as organic amendments [65,105].

With respect to the $\mathrm{C}_{\mathrm{mic}} / \mathrm{N}_{\text {mic }}$ relationship, this has sometimes been used to describe the structure and state of the microbial community [106]. On the other hand, the $\mathrm{C}_{\mathrm{mic}} / \mathrm{N}_{\text {mic }}$ ratio of microbial isolates, extracted from soils or obtained from culture collections and cultivated under optimal conditions, varies from 7 to 12 in fungi and from 3 to 6 in bacteria [24]. The results obtained in this study of $\mathrm{C}_{\text {mic }} / \mathrm{N}_{\text {mic }}$ varied from 3.82 to 11.66 (Table 3) and presented significant differences $(\mathrm{F}=23.377, p=0.000$ ) between the seasons of the year. During spring and summer, $C_{\text {mic }} / N_{\text {mic }}$ values were $>11$, with no significant differences $(\mathrm{F}=0.019, p=0.898)$ between these 2 seasons of the year. However, in autumn and winter, the $C_{\text {mic }} / \mathrm{N}_{\text {mic }}$ ratio was $<5$, and there were also no significant differences $(F=1.992$, $p=0.231$ ) between them. With these results, it was deduced that in spring and summer there was a greater predominance of fungi in the microbiota of biosolids, while in autumn and winter there was a greater predominance of bacteria. The predominance of microbial flora in biosolids can also be attributed to climatic conditions, as in spring and summer 2018 the local ambient temperature ranged from 11.93 to $30.97^{\circ} \mathrm{C}$ and 13.83 to $27.76^{\circ} \mathrm{C}$, respectively, in autumn and winter 2018 it ranged from 11.70 to $25.83^{\circ} \mathrm{C}$ and 6.27 to $24.27^{\circ} \mathrm{C}$, respectively [112]. Thus, fungal growth is promoted in a temperature range of 20 to $40{ }^{\circ} \mathrm{C}$ [113], while for bacteria the range is 4 to $60{ }^{\circ} \mathrm{C}$ [114]. With this information, it is possible to explain the predominance of fungi in spring and summer and bacteria in autumn and winter.

With respect to the enzymatic activity of dehydrogenase (DSH), this enzyme is an indicator of microbial activity in biological systems such as biosolids, reflecting primary metabolism and cellular respiration because it only occurs in viable cells $[115,116]$. In the biosolids evaluated at different times of the year, values of 2209.51 to $2426.10 \mathrm{mg}$ INF kg-1 dry biosolids $\mathrm{h}^{-1}$ were found. The DSH of the biosolids did not present significant differences $(\mathrm{F}=3.009, p=0.095)$ at the different times of the year. With this it can be considered that, independently of the time of the year in which the biosolids were produced, their microbiota presented a similar cellular respiratory activity and primary metabolism. On the other hand, the DSH activity of the biosolids analysed was higher than that reported in the literature in soils with different management histories [117-119]. Pascual et al. [120] studied the activity of DSH as a biomarker of degradation and remediation processes in abandoned natural and agricultural soils. They observed that natural soils had higher DSH activity (61.2 $\mathrm{mg} \mathrm{INF} \mathrm{kg}^{-1}$ dry soil $\mathrm{h}^{-1}$ ) compared to soils without agricultural activity for different periods. The decrease in DSH activity, which they reported over time, was attributed to the progressive erosion of soils without agricultural activity because of low levels of organic matter. Other studies applying biosolids to agricultural soils as an organic amendment have shown that DSH activity in soils increases with the addition of biosolids, which has been attributed to a high content of labile organic matter present in biosolids [121-123]. However, biosolids have not been considered to present a high DSH activity as evaluated in this study (DSH activity $>2000 \mathrm{mg} \mathrm{INF} \mathrm{kg}^{-1}$ biosolids $\mathrm{h}^{-1}$ ). Therefore, the addition of these biosolids to soils would be expected to increase DSH activity, not only because of their high organic matter content, but also because of the contribution of an active microbiota with available enzymatic machinery adapted to the organic matter present in the biosolids. Finally, to obtain information as observed from the evaluated enzymatic activity (DSH), before the addition of biosolids to agricultural soils, this information could be used to predict, with more ecological and biological arguments, the positive or negative effects of microbial interactions in agricultural soils with added biosolids.

On the other hand, with respect to the secondary metabolism of microorganisms, which is related to reserve energy consumption [56], microbial activity was determined by hydrolysis of fluorescein diacetate (FDA) in biosolids. Fluorescein diacetate is hydrolysed by proteases, lipases, and esterases, which are enzymes involved in the microbial breakdown of organic matter $[32,124]$. At different times of the year, biosolids presented an FDA activity between 279.71 and $437.96 \mathrm{mg}$ Fluorescein $\mathrm{g}^{-1}$ dry biosolids $\mathrm{h}^{-1}$ (Table 3). Significant differences $(\mathrm{F}=10.270, p=0.004)$ from FDA between different 
seasons of the year were observed. In summer, it presented the lowest FDA activity (279.71 mg Fluorescein $\mathrm{kg}^{-1}$ dry biosolids $\mathrm{h}^{-1}$ ), and in autumn, the highest activity (437.96 mg Fluorescein $\mathrm{kg}^{-1}$ dry biosolids $\mathrm{h}^{-1}$ ). These values obtained at different times of the year could be due to the availability of energy reserve compounds in the biosolids, mainly lipids, esters and proteins as observed in the spectra of the FTIR analyses (Figures 1 and 2, Table 3). The observed increase in FDA activity was also related to a high content of labile organic matter in the evaluated biosolids, i.e., easily mineralizable organic compounds available as substrates for microbial metabolism [105,125]. However, the values obtained for biosolids evaluated independently of the season of year were higher than those reported in the literature in soils and soils with added biosolids [66,126,127]. Gajda et al. [124] evaluated the changes in FDA activity of 2 types of soil, 1 silty and the other sandy, without addition of organic amendments and with the same types of tillage, finding that FDA activity ranged from 50.50 to $126.70 \mathrm{mg}$ fluorescein $\mathrm{kg}^{-1}$ dry soil $\mathrm{h}^{-1}$ and from 40.20 to $77.20 \mathrm{mg}$ fluorescein $\mathrm{kg}^{-1}$ dry soil $\mathrm{h}^{-1}$, respectively. These results were lower than those obtained in this study for biosolids of all seasons of the year; even in summer the value obtained was 2.2 times higher than the highest value obtained in the silty soil evaluated in that study. On the other hand, Carlson et al. [127], evaluated the effect on FDA activity by adding organic amendments to an agricultural soil with 5 treatments: (1) control; (2) $137 \mathrm{mg}$ urban vegetative compost $\mathrm{ha}^{-1}$; (3) $202 \mathrm{mg}$ biosolids ha ${ }^{-1}$; (4) $404 \mathrm{mg}$ biosolids ha $^{-1}$ and (5) designed mixture (202 mg biosolids $\mathrm{ha}^{-1}, 10.3 \mathrm{mg}$ biochar ha ${ }^{-1}$, and $5.7 \mu \mathrm{g} \mathrm{Fe}_{2} \mathrm{O}_{3}$ oxide ha ${ }^{-1}$ ), obtaining values of 38, 90, 75, 50, and $70 \mathrm{mg}$ fluorescein $\mathrm{kg}^{-1}$ dry soil ha ${ }^{-1}$, respectively. Thus, Carlson et al. [127], established that the organic amendments they used significantly increased FDA activity in soil, especially with biosolids, and suggested that organic amendments may contain extracellular hydrolytic enzymes or microorganisms that have these enzymes. With the results obtained in this study, the FDA's activity in biosolids could be demonstrated as suggested by Carlson et al. [127], and then it would be expected that by adding the biosolids evaluated in the present study to an agricultural soil, they would provide labile organic matter and enzymatic machinery already prepared for their degradation. In summary, an increase in FDA activity is expected by adding the evaluated biosolids to soils, as similarly reported in previous studies $[66,125,127]$.

Barragán-Sánchez et al. [56], established a biosolids stability index expressed as DHS/FDA, providing information about the predominance between the primary metabolism (breathing processes, etc.) and the secondary metabolism (consumption of energy reserves) in the microorganisms present. If the DHS/FDA quotient is small, it can be mentioned that the secondary phase of metabolism referring to endogenous processes predominates in the system and vice versa. The results obtained in the biosolids analysed for this DHS/FDA index ranged from 5.55 to $7.99 \mathrm{mg} \mathrm{INF} \mathrm{mg}^{-1}$ Fluorescein, and there were no significant differences $(\mathrm{F}=3.96, p=0.069)$ between the seasons of the year (Table 3). The results obtained from DHS/FDA were lower than those obtained by Barragán-Sánchez et al. [56], who obtained values of 58 to $10 \mu \mathrm{mol} \mathrm{O}_{2} \mu \mathrm{mol}^{-1}$ FDA hydrolysed (equivalent to 164.49 to $28.37 \mathrm{mg}$ INF $\mathrm{mg}^{-1}$ Fluorescein) during the monitoring of an aerobic process of stabilisation of residual sludge. With this it could be established that the secondary metabolism was the dominant one in the evaluated biosolids. The biosolids evaluated were a stabilised solid residue that is in a more markedly endogenous phase. Thus, when adding biosolids to agricultural soils, total enzyme activity in the soil would be expected to increase because the biosolids are in the endogenous phase, i.e., the microorganisms present are adapted and consume energy reserves for the production of hydrolytic enzymes that transform current organic matter into energy for the maintenance process $[43,128]$. This behaviour may also be related to the quality of organic matter present in biosolids [92,93], which according to the FTIR spectra observed (Figures 1 and 2), was stable and with little variability during the different seasons of the year. Therefore, the type and quantity of substrates available in biosolids has a significant influence on the development and predominance of the endogenous phase of the microorganisms present. In the same way, it can be established that the evaluated biosolids possess, besides labile organic matter, extracellular enzymes ready for the process of mineralisation of organic matter. 
In reference to the evaluation of extracellular enzymatic activities, the activity of urease (URS) in biosolids in different seasons of the year was evaluated. URS is an enzyme that catalyses the hydrolysis of urea into carbon dioxide and ammonia by acting on the $\mathrm{C}-\mathrm{N}$ bonds of different peptides [129]. Therefore, the activity of the URS is of great importance in the biotransformation processes of nitrogenous organic compounds [99]. The values reached for the activity of URS in the biosolids analysed at different times of the year ranged from 109.82 to $194.55 \mathrm{mg} \mathrm{N}^{-\mathrm{NH}_{4}}{ }^{+} \mathrm{kg}^{-1}$ dry biosolids h${ }^{-1}$ (Table 3). The activity of the URS in the biosolids evaluated for the autumn presented significant differences $(\mathrm{F}=17.771, p=0.001)$ with respect to the rest of the year and was also the lowest value obtained (109.82 ${\mathrm{mg} \mathrm{N}-\mathrm{NH}_{4}}^{+} \mathrm{kg}^{-1}$ dry biosolids $\mathrm{h}^{-1}$ ). This could indicate that in autumn there could have been fewer nitrogenous organic compounds than in the rest of the year, so less urease enzyme activity was required. Previous research has focused on evaluating the effect of URS activity in agricultural soils with added biosolids but has not considered evaluating URS activity in biosolids per se for a better understanding of the mineralisation processes of nitrogen compounds after the addition of biosolids to soils. In investigations on the application of biosolids in agricultural soils, an increase in the activity of URS has been observed; however, the values obtained have oscillated from 20 to $100 \mathrm{mg}$ of N-NH${ }_{4}^{+} \mathrm{kg}^{-1}$ dry soil $\mathrm{h}^{-1}[108,122,127,129]$. However, the results of the URS activity obtained in these studies were lower than those obtained in this paper. This enzymatic activity then becomes an indicator of the presence and potential contribution of nitrogenous sources of biosolids when applied to soils. On the other hand, with the results obtained, the importance of evaluating the activity of the URS in agricultural soils when biosolids are applied as organic amendment in short (maximum 180 days of incubation in laboratory experiments) and long ( $>1$ year in field experiments) treatments was also established. Kizılkaya and Bayrakl1 [129] evaluated the effect of the addition of biosolids on URS activity at different doses of biosolids $\left(0,100,200\right.$, and 300 ton ha $\left.^{-1}\right)$ in agricultural soil in a short-term laboratory-scale incubation experiment (90 days incubation). In these experiments it was observed that the activity of the URS increased rapidly until reaching a maximum activity in 15 days after the application of the biosolids; then, the activity of the URS decreased significantly until reaching values below the initial values (day 0 ) at 90 days of incubation. However, other long-term studies (1 and 4 years, respectively) conducted by Roig et al. [122] and Carlson et al. [127] agreed that URS activity was not affected by the addition of biosolids to agricultural soils. Thus, the increase in URS activity in soils with short-term application of biosolids could be a consequence of the stimulation of endemic soil microorganisms by the addition of $\mathrm{N}$ present in biosolids, increasing their metabolic capacity, and therefore, the production and activity of the urease enzyme. However, this increase in URS activity in agricultural soils with the addition of biosolids in the short-term applications could also be attributed to the fact that biosolids provide both labile organic matter and microorganisms with active enzymatic machinery ready for $\mathrm{N}$ transformation. Hence, the importance of evaluating URS activity in biosolids before application to soil becomes clear, especially since biosolids have been presented as an organic amendment with an important content of nitrogen compounds, such as amides, peptides and proteins, as observed in studies and analysis of FTIR spectra (Figures 2 and 3). Determining this enzymatic activity over time and in biosolids can be a usable indicator of quality and functionality to ensure the biotransformation of nitrogen-rich organic matter in soils prior to application.

Other biological parameters related to soil quality and functionality that have been used in assessing the effect of organic amendments such as biosolids on agricultural soils are the metabolic quotient $\left(\mathrm{qCO}_{2}\right)$ and specific hydrolytic activity (qFDA) $[47,66,130]$. The $\mathrm{qCO}_{2}$ expresses the amount of $\mathrm{CO}_{2}$ produced per unit of biomass and time. This indicator has been used as an indicator of the physiological status of microorganisms in biosolids [66,131]. The $\mathrm{qCO}_{2}$ has also been used to detect alterations or stress of $\mathrm{MB}$ in the soil or in organic amendments due to disturbances or environmental changes $[63,66,72]$. The $\mathrm{qCO}_{2}$ obtained in the biosolids analysed in this study for each time of year

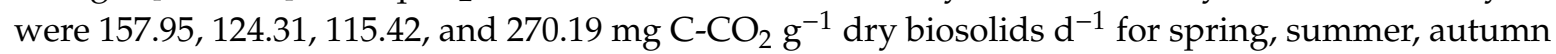
and winter, respectively. Winter $\mathrm{qCO}_{2}$ was significantly different $(\mathrm{F}=41.951, p=0.000)$ from the rest of the year. Therefore, it can be attributed that during the winter the biosolids presented an alteration 
that allowed them to increase their respiration rate (Table 3). This increase could be possibly due to a lower MB content or climatic conditions, as already mentioned. The lower MB content or climatic conditions can propitiate a structural change of the microbial community [113]. Although there are no reported data in the literature on $\mathrm{qCO}_{2}$ for biosolids per se, Sciubba et al. [66] established that $\mathrm{qCO}_{2}$ in soils amended with biosolids presented a greater impact as the application rate of biosolids to the soil increased, thus confirming that $\mathrm{qCO}_{2}$ can emphasise the effects of biosolids on soil properties. Tian et al. [131] in a field study on the application of biosolids to agricultural soils in the long term ( $>20$ years) found that $\mathrm{qCO}_{2}$ was lower in soil with application of biosolids than control soil without biosolids, thus concluding that there was an improvement in the microbial metabolism of $\mathrm{C}$ as a result of stress relief in soil microorganisms, due also to an increase in $\mathrm{C}$ sequestration in soils with biosolids. Thus, they expanded the concept of $\mathrm{qCO}_{2}$ to assess microbial stress relief and restoration of microbial physiology in agricultural soils with biosolids amendment. Lloret et al. [72] evaluated the application of 2 types of biosolids: aerobic thermophilic (AT) and anaerobic mesophilic (AM) to an agricultural soil to establish if there are differences of these biosolids according to the stabilisation processes with which they were obtained and found that $\mathrm{qCO}_{2}$ was higher in the soil with biosolids AM both with respect to the control soil (without amendment), as well as in the soil with biosolids AT. They concluded that AT biosolids produced minor changes in soil microbiota and improved soil microbial activity. Therefore, it is important to monitor these parameters in biosolids before their application to agricultural soils, to expect or not possible alterations to the soil microbiota and therefore to establish an adequate management of biosolids.

The qFDA is an index established by Perucci et al. [30] and was based on the measurement of the global hydrolytic capacity of a specific microbial biomass. The qFDA expresses the ratio of hydrolysed fluorescein diacetate (FDA) per C unit of microbial biomass [126,132]. This index has been used mainly for the evaluation of soil disturbance and stress due to the presence of xenobiotics [126]. The interest in using qFDA in the analysed biosolids was based on establishing if this parameter can be a useful tool, on the global hydrolytic activity and as a function of the $\mathrm{C}$ stored in the BM of the biosolids, which is very similar to how they have been used in soils $[132,133]$. The qFDA results obtained in the biosolids analysed for each season of the year were 356.27, 223.27, 381.57, and $636.39 \mathrm{mg}$ Fluorescein $\mathrm{g}^{-1} \mathrm{C}_{\text {mic }} \mathrm{h}^{-1}$ for spring, summer, autumn and winter, respectively (Table 2). The winter, qFDA was significantly different $(\mathrm{F}=23.371, p=0.000)$ from the rest of the year. This behaviour was like that obtained for $\mathrm{qCO}_{2}$, presenting the highest values. Yakushev et al. [130] conducted studies on the effect on the physiological state of the microbial community in compost and vermicompost, revealing higher $\mathrm{qCO}_{2}$ and $\mathrm{qFDA}$, indicating that organic matter is less accessible to microorganisms and that there is a greater consumption of energy for oxidation of substrates. Sánchez-Monedero et al. [126] evaluated the effect on qFDA dynamics during the application of biosolids compost to agricultural soils in an incubation experiment at 60 days. These researchers observed that qFDA was characterised by stable values during incubation time, i.e., qFDA dynamics were not affected by incubation time and addition of biosolids. Thus, it can be deduced that in winter the biosolids under study presented a more complex chemical composition, probably due to the presence of recalcitrant compounds, with respect to the other seasons of the year, presumably making the organic matter of the biosolids less accessible in winter. So, it can be established that the qFDA parameter in biosolids could be a useful quality and functional indicator, giving valuable information on the accessibility of organic matter in biosolids before its application to soils.

Biological parameters evaluated in biosolids, such as MBC and MBN content, as well as, the $\mathrm{C}_{\text {mic }} / \mathrm{N}_{\text {mic }}$ ratio, demonstrated that biosolids have a significant content of active microorganisms, which could be produce a "positive synergistic" effect on the activity of soil microorganisms. In addition, in the biosolids evaluated over time, it has been possible to elucidate a high metabolic activity (DSH, FDA, and URS activity), presumably due to the content of substrates such as polysaccharides, proteins, fats and lipids that are easily assimilated by the microorganisms present. In addition, the DSH/FDA ratio established a predominance for secondary metabolism due to the presence of energy reserve compounds 
already mentioned. Due to the active enzymatic machinery, this will facilitate the mineralisation of the organic matter of the biosolids, reducing the energetic barrier for the decomposition of the foreign complex organic matter for the microorganisms of the soil. The $\mathrm{qCO}_{2}$ and $\mathrm{qFDA}$ allowed for the evaluation of the physiological state of the microorganisms of the evaluated biosolids, giving information through time about their capacity to assimilate the organic matter present in the biosolids, which will depend on the labile or complex chemical composition it has. Thus, having information on the biological/biochemical/molecular status of biosolids before their application to soils will allow predicting possible positive as well as negative effects on them, and thus will allow making better decisions on the management and disposal of these biosolids as an amendment or soil improvers, especially agricultural ones.

\subsection{Extracellular Enzyme Profiles per API ZYM ${ }^{\circledR}$ Kit for Biosolids}

The mineralisation of organic matter is mainly mediated by microorganisms, which possess the adequate enzymatic machinery to obtain the energy necessary to carry out their metabolic processes [39,134]. The enzymes involved in the degradation of organic matter can be divided into hydrolytic enzymes that are responsible for the acquisition of $\mathrm{C}, \mathrm{N}$ and $\mathrm{P}$ to support primary and oxidative metabolism, oxidative enzymes that degrade recalcitrant compounds such as lignin during in the acquisition of nutrients $[135,136]$. These groups of enzymes may respond differently to the addition of organic amendments such as biosolids. Torri et al. [62] stated that the addition of biosolids to soils can improve and maintain biological activity in soils over the long term. However, little information is available on the enzymatic activity of biosolids due to the lack of methodologies or analytical methods that provide information quickly and inexpensively. In recent decades, the API $\mathrm{ZYM}^{\circledR}$ system has been used and validated to evaluate enzymatic profiles of soils, compost, activated sludge and sediments $[34,36-39,44,134,137,138]$. However, the API ZYM ${ }^{\circledR}$ system has not been used directly and over time in biosolids samples as a system for the rapid determination of 19 extracellular hydrolytic enzymatic reactions related to the $C, N$ and P cycles. The objective of using the API ZYM ${ }^{\circledR}$ system to evaluate biosolids at different season of the year was to quickly obtain information on the extracellular enzyme profile of biosolids. With the information obtained, it could be used as a background on the possible positive or negative effects on soil functional diversity when biosolids are used as an organic amendment. The extracellular enzyme profile of the biosolids analysed for each season of year is shown in Figure 4. The enzyme activity was classified into 5 families: (1) phosphatases (catalyses the removal of phosphate groups from substrates as nucleic acids), (2) esterases-lipases (hydrolyse ester bonds mainly in fats and oils), (3) aminopeptidases (hydrolyse peptide bonds in peptides), (4) proteases (hydrolyse peptide bonds in proteins) and (5) glycosyl hydrolases (catalyses the hydrolysis of glycosidic bonds in carbohydrates). The enzymatic activities presented differences and similarities for each season of the year.

In spring, a mainly moderate enzymatic activity was obtained (Figure 4). Within the 19 enzymes determined in biosolids in March and April, only 1 enzyme showed no activity, and it belonged to the family of glycosyl hydrolases. In biosolids produced in May, there were no activities of 3 enzymes, 2 glycosyl hydrolases and 1 protease. Low enzymatic activity in 4, 7 and 5 enzymes were detected in biosolids for March, April, and May, respectively. These enzymes belonged to the families esterases-lipases, aminopeptidases, proteases and glycosyl hydrolases (Figure 4). The enzyme activity of the biosolids was moderate for March, April, and May in 10, 6 and 8 enzymes, respectively, and were distributed within the 5 families. In March, April and May biosolids, high enzyme activity was presented for 4, 5 and 3 enzymes, respectively, mainly from the phosphatase family.

In summer, the enzyme profile of biosolids showed a predominantly high enzyme activity for all enzyme families. Undetected enzyme activity was obtained for 1 glycosyl hydrolase enzyme in June and July biosolids, while in August there were 2 enzymes, 1 glycosyl hydrolase and the other aminopeptidase. In June, low biosolids biological activity was obtained for 3 enzymes of the glycosyl hydrolases and aminopeptidases families. Moderate summer enzyme activity was presented in 9, 6 
and 3 enzymes for June, July and August biosolids, respectively (Figure 4). The esterases-lipases and aminopeptidases families were the main ones that presented moderate enzymatic activity. The high enzyme activity for June, July and August biosolids was exhibited in 6, 12 and 4 enzymes, respectively. The families of phosphatases, proteases and glycosyl hydrolases had an important activity in summer.

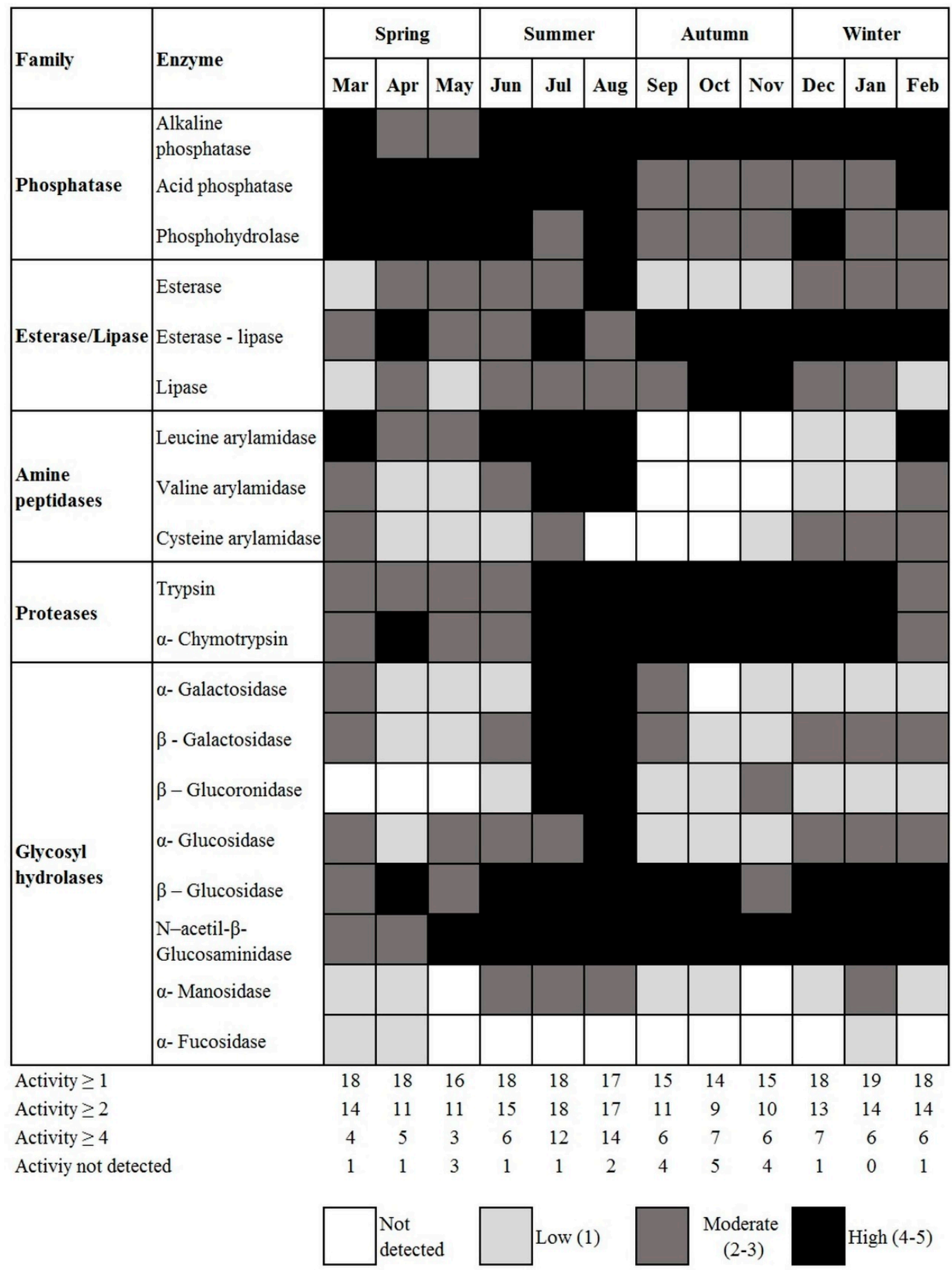

Figure 4. Profile of 19 extracellular enzymes determined by the API ZYM ${ }^{\circledR}$ system in the biosolids analysed during one year of UWWTP operation. The shading in the table represents the relative abundance of enzymes. The values are as follows: White, not detected; light grey, low intensity reactions (value $=1$ ); dark grey, moderate intensity reactions (value $=2$ and 3 ); black, high intensity reactions (value $=4$ and 5). The number of enzymes showing reactions $\geq 1, \geq 2$ and $\geq 4$, as well as the total number of enzymes showing no activity for each month are indicated below each column. 
In autumn, the enzyme activity of biosolids was moderate to high; however, this was the season of the year with the highest number of enzymes with undetected activity. In September and November there was undetected enzyme activity in 4 enzymes, and in October there was undetected enzyme activity in 6 enzymes. The aminopeptidase family showed no enzyme activity in any of the biosolids samples analysed for the fall. There was low enzyme activity in September and October in the biosolids observed in this phenomenon in 4 enzymes. In November this low activity was only present in 5 enzymes. Most of the low activity enzymes were glycosylhydrolase. With moderate enzyme activity, 5, 2 and 4 enzymes were obtained for the September, October and November biosolids, respectively (Figure 4). The predominant moderate enzymatic activity in the biosolids in the autumn season corresponded to phosphatases, being that this time of the year was the one that had less enzymatic activity for this family of enzymes in the analysed biosolids. Finally, for the biosolids analysed in autumn in the months of September and November, the number of enzymes with high activity was 6 and 7 for the biosolids of October, mainly from the families of proteases and hydrolases of glycosil.

In winter, the enzymatic activity of the biosolids analysed in a different season of the year was moderate to high. In the biosolids of December and February, the enzyme $\alpha$-Fucosidase showed no activity. Low enzyme activity was detected for 5 enzymes in December and January and 4 enzymes for February, mainly from the aminopeptidase family. Thus, moderate enzyme activity for December biosolids was obtained in 6 enzymes, and for January and February biosolids, 8 enzymes were distributed in the 5 families (Figure 4). Finally, 7 enzymes presented high activity for December and 6 enzymes for January and February, with the proteases and glycosyl hydrolases families standing out.

The extracellular enzyme profile (Figure 4) showed that 9 enzymes were similar in "intensity" during different season of the year (acid phosphatase, phosphohydrolase, alkaline phosphatase, esterase lipase, trypsin, $\alpha$-chemotrypsin, $\beta$-glucosidase, $N$-acetyl- $\beta$-glucosaminidase, $\alpha$-fucosidase). On the other hand, 10 enzymes showed differences in intensity during different season of the year (esterase, lipase, leucine arylamidase, valine arylamidase, cysteine arylamidase, $\alpha$-galactosidase, $\beta$-galactosidase, $\beta$-glucoronidase, $\alpha$-glucosidase and $\alpha$-manosidase). These results demonstrated that biosolids are not only a source of organic matter, but also have an important contribution of hydrolytic enzymes, confirming the importance of evaluating the biological parameters in biosolids prior to their addition to soils. However, the enzymatic machinery of the biosolids varied in the intensity of their activity in more than $50 \%$ of the 19 enzymes. Nevertheless, in average for all seasons of the year, 13 enzymes present an activity with a moderate to high intensity, which can positively influence the mineralisation processes of organic matter, mainly in hydrolysis process considered as the limiting stage of the transformation process of organic matter [139]. Extracellular soil enzymes are synthesised and secreted by soil microorganisms and are the proximate agents of organic matter formation and decomposition [140]. The activities of soil enzymes can provide useful information on the mechanisms of microbial sensitivity to the addition of $\mathrm{C}, \mathrm{N}$ and P. From the above, the importance of establishing that enzymatic activities exist in biosolids before their application to matrices that are also complex in their enzymatic machinery, such as soils, is further emphasised. Thus, it is possible to elucidate even more that enzymatic activities are predominant and which ones cease or which changes exist after the application of these biosolids and how to correlate them with the processes of mineralisation, assimilation and maintenance of sources of $\mathrm{C}, \mathrm{N}$ and $\mathrm{P}$ in soils.

Also, depending on the results of this study, the importance of knowing beforehand and its evolution over time of enzymes and their activities in biosolids to further elucidate the possible synergies or ecological relationships of microorganisms of biosolids and their enzymes with microorganisms and their hydrolytic enzymes in the soil that support the primary and oxidative metabolism for the acquisition of sources of $\mathrm{C}, \mathrm{N}$ and $\mathrm{P}$ was established. The study also established the importance of knowing beforehand the evolution of enzymes and their activities in biosolids to further elucidate the possible synergies or ecological relationships of microorganisms of biosolids and their enzymes with the microorganisms and their hydrolytic enzymes in the soil that support the primary and oxidative metabolism for the acquisition of sources of $\mathrm{C}, \mathrm{N}$ and $\mathrm{P}$. An example of possible and complex 
enzymatic relationships of the addition of organic amendments to soil can be established with the one reported by Wang et al. [140], who reported that the increase of $\mathrm{N}$ inputs increased the activity of $N$-acetyl- $\beta$-glucosaminidase but decreased the activity of $\beta$-glucosidase in 3 sizes of soil aggregates.

The profile of the 5 families of extracellular enzymes in biosolids, evaluated in the different seasons of the year, was compared based on their contribution percentages of their analysed activities (Figure 5). The microbial communities of the analysed biosolids reflected a variation in their availability to synthesise hydrolytic extracellular enzymes in different seasons of the year. In general, the family of enzymes, phosphatase, esterase/lipase and glycosyl hydrolase, which are related to the P and C cycles, were more actively synthesised in biosolids regardless of the season and they were not statistically different $(\mathrm{F}=1.921, p=0.20 ; \mathrm{F}=1.569, p=0.272 ; \mathrm{F}=1.325, p=0.332$, respectively). However, in the 2 families of enzymes related to the $\mathrm{N}$ cycle, amine peptidases and proteases, the behaviour was different. In the amino peptidases no significant difference was found $(\mathrm{F}=2.078, p=0.182)$ at any time of the year. However, significant differences were found in the proteases evaluated in biosolids at different times of the year $(\mathrm{F}=5.547, p=0.023)$. Thus, the biosolids have an active hydrolytic enzymatic machinery during different seasons of the year, but their synthesis is not constant at all times and can be attributed to the chemical composition and the variable content of microbial biomass in the biosolids (see Table 3).

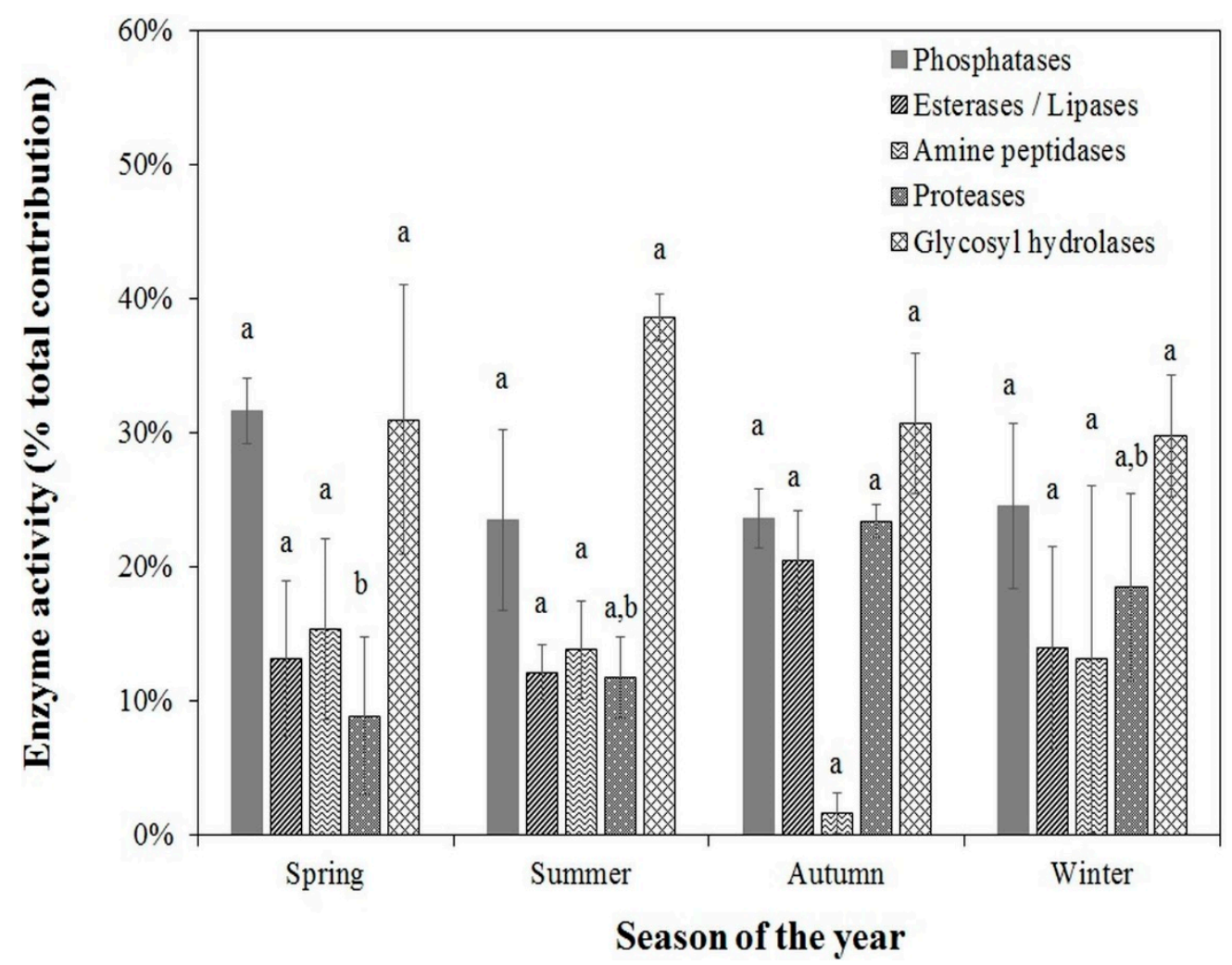

Figure 5. Contribution of extracellular enzyme activity separated into families for biosolids obtained at different times of the year. The bar represents the standard deviation of 3 replicates. Different letters on each column represent significant difference for that family of enzymes between seasons of the year.

Some mathematical indices have been used to describe the "richness and distribution" of species of organisms in a community, including the Shannon Diversity Index $\left(\mathrm{H}^{\prime}\right)$ and the Synthetic Enzyme Index (SEI). The Shannon Diversity Index reflects the heterogeneity of a community based on 2 factors: the number of species (richness) and their relative abundance $[59,141]$. Shannon diversity index values were generally between 1.5 and 4.0 , where values close to 1.5 indicate low diversity, and values close to 4.0 indicate high diversity [142]. In addition, the Shannon Diversity Index has been used to 
describe the status of the microbial community and its response to stress caused by disturbances in the environmental matrix [39]. Thus, stressed microbial communities with low diversity are less adapted to cope with environmental changes and stress than biologically adapted communities with a higher degree of diversity $[109,143]$. Shannon diversity index calculations obtained in this study for different seasons of the year ranged from 2.46 to 2.78 (Table 4). In addition, the results obtained did not present significant differences $(\mathrm{F}=0.989, p=0.445)$ between seasons of the year. With this, it can be deduced that the microbial diversity present in biosolids was similar always of the year and that their diversity was catalogued as average. These results meant that biosolids, regardless of the season of year in which they were obtained, were homogeneous in terms of both the number of microbial species and their relative abundance. Therefore, they can be considered with a biologically adapted microbial community capable of tolerating environmental changes and stress. Thus, biosolids being used as an organic amendment in soils can be expected to have a positive effect on the processes of adaptation and changes in the microbial structure of soils. Finally, the Shannon index could contribute to providing valuable information on the degree of biological stability (bioindicator) of a biosolid, applicable to agricultural soils as an organic amendment. This bioindicator would be based on the determination of microbial diversity as a function of changes in its enzymatic activities, especially when there is a lack of information on the composition of the structure and its microbial functioning in biosolids.

Table 4. Indices of microbial and functional diversity of biosolids collected and evaluated in the UWWTP at different season of the year.

\begin{tabular}{ccccc}
\hline \multirow{2}{*}{ Parameters } & \multicolumn{4}{c}{ Biosolids Analysed for Each Season of the Year } \\
\cline { 2 - 5 } & Spring & Summer & Autumn & Winter \\
\hline H' & $2.61 \pm 0.08 \mathrm{a}$ & $2.78 \pm 0.17 \mathrm{a}$ & $2.46 \pm 0.12 \mathrm{a}$ & $2.60 \pm 0.10 \mathrm{a}$ \\
$*$ SEI & $293.3 \pm 63.3 \mathrm{~b}$ & $488.3 \pm 115.6 \mathrm{a}$ & $311.7 \pm 36.9 \mathrm{a}, \mathrm{b}$ & $331.7 \pm 40.7 \mathrm{a}, \mathrm{b}$ \\
\hline
\end{tabular}

The results are the mean \pm standard deviation (3 replicates). Rows with different letters are significantly different according to Tukey's analysis with $p \leq 0.05 .{ }^{*}$ (nmol hydrolysed substrate).

The synthetic enzymatic index (SEI) is an index that represents the sum of all enzymatic activities in the evaluated environmental matrix $[33,143]$, as well as the metabolic activity or biochemical functioning of the evaluated substrate or, in this case, the biosolids [31,143]. The SEI then becomes a "biochemical fingerprint" [33]. The maximum and minimum SEI values were $760 \mathrm{nmol}$ hydrolysed substrate (high functional diversity) and $0 \mathrm{nmol}$ hydrolysed substrate (low functional diversity); this is because it was obtained through the sum of the 19 hydrolytic enzymes obtained in the APIZYM system for each biosolid. The SEI in biosolids ranged from 293.33 to $488.30 \mathrm{nmol}$ hydrolysed substrate at different season of the year and were significantly different $(\mathrm{F}=4.721, p=0.033)$. The lowest SEI value (293.33 nmol hydrolysed substrate) was obtained in spring, and the highest ( $488.30 \mathrm{nmol}$ hydrolysed substrate) was obtained in summer. In autumn and winter, the values of SEI were 311.72 and $331.79 \mathrm{nmol}$ hydrolysed substrate and were not different from each other $(\mathrm{F}=0.398, p=0.562)$ compared to those from the other seasons of the year. Thus, it can be established that the functional diversity of biosolids is within a medium activity. The SEI can also relate microbial enzymatic activities to the degradation processes of organic matter-that is, the greater the enzymatic activity, the greater the degradation of organic matter and vice versa [31]. Thus, it was established that biosolids in spring had less potential for organic matter degradation than those obtained in summer. Therefore, this parameter is important for biosolids to be used as an organic amendment, since having a high SEI could have a greater impact on processes related to the degradation and mineralisation of organic matter added to the soil and the recycling of its nutrients.

\subsection{Relationship between Biological and Physicochemical Parameters and Nutrient Content}

Analysis of the establishment of possible relationships of biological parameters linked to nutrients and physicochemical parameters were established. This was done in order to see dependencies or 
influences of the biological parameters on those. A product-moment correlation of Pearson was made (Table 5). Significant correlations occurred for $\mathrm{MBC}, \mathrm{MBN}, \mathrm{C}_{\mathrm{mic}} / \mathrm{N}_{\text {mic }}$, DSH activity, FDA activity, URS activity, $\mathrm{qCO}_{2}, \mathrm{qFDA}, \mathrm{H}^{\prime}$ and SEI. MBC correlated positively with TOC, $\mathrm{C} / \mathrm{N}, \mathrm{Fe}, \mathrm{B}$ and $\mathrm{Mn}$ and negatively with $\mathrm{P}, \mathrm{Zn}, \mathrm{Cu}, \mathrm{qCO}_{2}$ and $\mathrm{qFDA}$. MNB had positive correlations with $\mathrm{B}$ and FDA and negative correlations with $\mathrm{K}, \mathrm{Zn}, \mathrm{Cu}, \mathrm{C}_{\text {mic }} / \mathrm{N}_{\text {mic }}$ and $\mathrm{H}^{\prime}$. The $\mathrm{C}_{\text {mic }} / \mathrm{N}_{\text {mic }}$ relationship correlated positively with EC, URS and $\mathrm{H}^{\prime}$ and negatively with FDA and qFDA. The DSH activity only presented negative correlation with SEI. The FDA activity presented negative correlations with Fe, URS and $\mathrm{H}^{\prime}$. URS activity correlated positively with $\mathrm{K}, \mathrm{Cu}$ and $\mathrm{H}^{\prime}$ and negatively with $\mathrm{B}$ and $\mathrm{N}-\mathrm{MB}$. The $\mathrm{qCO}_{2}$ showed positive correlations with $\mathrm{Zn}, \mathrm{Cu}$, and qFDA and negative correlations with TOC, B and $\mathrm{Mn}$. qFDA correlated positively with TOC and $\mathrm{Zn}$ and negatively with $\mathrm{C} / \mathrm{N}, \mathrm{Fe}$ and $\mathrm{Mn}$. With respect to $\mathrm{H}^{\prime}$ index, there was a positive correlation with Fe and SEI. SEI correlated positively with TOC, Fe and Mn.

Table 5. Pearson's product moment correlation coefficient between biological and physicochemical parameters in the biosolids collected and evaluated in the UWWTP at different season of the year.

\begin{tabular}{|c|c|c|c|}
\hline Parameters & Correlation Coefficient $\left(r^{2}\right)$ & Parameters & Correlation Coefficient $\left(\mathrm{r}^{2}\right)$ \\
\hline MBC & \multicolumn{3}{|c|}{ FDA Activity } \\
\hline TOC & $0.798^{* *}$ & $\mathrm{Fe}$ & $-0.585^{*}$ \\
\hline $\mathrm{C} / \mathrm{N}$ & $0.643 *$ & URS & $-0.643 *$ \\
\hline $\mathrm{P}$ & $-0.585^{*}$ & $\mathrm{H}^{\prime}$ & $-0.832^{* * *}$ \\
\hline $\mathrm{Fe}$ & $0.646^{*}$ & & \\
\hline $\mathrm{B}$ & 0.693 * & URS Activity & \\
\hline $\mathrm{Mn}$ & $0.748^{* *}$ & $\mathrm{~K}$ & $0.578 *$ \\
\hline $\mathrm{Zn}$ & $-0.823^{* * *}$ & $\mathrm{~B}$ & $-0.702^{* *}$ \\
\hline $\mathrm{Cu}$ & $-0.631 *$ & $\mathrm{Cu}$ & $0.637 *$ \\
\hline $\mathrm{qCO}_{2}$ & $-0.957^{* * *}$ & $\mathrm{H}^{\prime}$ & $0.714^{* *}$ \\
\hline \multirow[t]{2}{*}{ qFDA } & $-0.899 * * *$ & & \\
\hline & & $\mathrm{qCO}_{2}$ & \\
\hline MBN & & COT & $-0.692 *$ \\
\hline K & $-0.707^{* *}$ & B & $-0.798^{* *}$ \\
\hline $\mathrm{B}$ & $0.753^{* *}$ & Mn & $-0.624 *$ \\
\hline $\mathrm{Zn}$ & $-0.660 *$ & $\mathrm{Zn}$ & $0.810^{* * *}$ \\
\hline $\mathrm{Cu}$ & $-0.791 * *$ & $\mathrm{Cu}$ & $0.650 *$ \\
\hline $\mathrm{C}_{\text {mic }} / \mathrm{N}_{\text {mic }}$ & $-0.729 * *$ & qFDA & $0.892^{* * *}$ \\
\hline FDA activity & $0.723 * *$ & & \\
\hline URS activity & $-0.900 * * *$ & qFDA & \\
\hline \multirow[t]{2}{*}{$\mathrm{H}^{\prime}$} & $-0.701^{* *}$ & TOC & 0.712 ** \\
\hline & & $\mathrm{C} / \mathrm{N}$ & $-0.580 *$ \\
\hline $\mathrm{C}_{\text {mic }} / \mathbf{N}_{\text {mic }}$ & & $\mathrm{Fe}$ & $-0.655 *$ \\
\hline EC & $0.794^{* *}$ & Mn & $-0.711^{* *}$ \\
\hline FDA activity & $-0.744^{* *}$ & $\mathrm{Zn}$ & $0.641 *$ \\
\hline URS & $0.618^{*}$ & & \\
\hline qFDA & $-0.647^{*}$ & $\mathbf{H}^{\prime}$ & \\
\hline \multirow[t]{2}{*}{$\mathrm{H}^{\prime}$} & $0.721^{* *}$ & $\mathrm{Fe}$ & $0.69 *$ \\
\hline & & SEI & $0.832 * * *$ \\
\hline \multicolumn{4}{|l|}{ DSH Activity } \\
\hline \multirow[t]{4}{*}{ SEI } & $-0.627^{*}$ & SEI & \\
\hline & & TOC & $0.613^{*}$ \\
\hline & & $\mathrm{Fe}$ & $0.803^{* *}$ \\
\hline & & $\mathrm{Mn}$ & $0.639 *$ \\
\hline
\end{tabular}

Only significant correlations are shown. The data include all biosolids samples collected in different seasons. ${ }^{*}, * *$ and ${ }^{* * *}$ indicate $p$ values less than $0.05,0.01$ and 0.001 , respectively $(\mathrm{n}=36)$.

Regarding the establishment of correlations between physicochemical and biological parameters (Table 5), it was observed that MBC, MBN, $\mathrm{C}_{\text {mic }} / \mathrm{N}_{\mathrm{mic}}, \mathrm{qCO}_{2}$, qFDA and URS activity could be used to predict the behaviour of some physicochemical properties such as TOC or of agronomic interest in biosolids samples. For example, a high MBC content would correspond to a high TOC content in 
biosolids ( $\mathrm{r}=0.798, p \leq 0.01)$, and a high MBN content would imply significant FDA microbial activity $(r=0.723, p \leq 0.01)$ in biosolids. Thus, these parameters could also be used as quality and functionality indicators of biosolids for use as organic amendment and predict the possible positive or negative effects of their addition to agricultural soils. Among the effects that could be highlighted could be the availability or loss of inorganic $\mathrm{N}$ in the soil, affecting the mineralisation processes of $\mathrm{C}$ and $\mathrm{N}$ as a consequence of the addition of a substrate with active microbial biomass in terms of MBC and MBN, as well as $\mathrm{qCO}_{2}$ and qFDA, as has been described in the literature by Scciuba et al. [105] and Molina-Herrera and Romanyà [111]. Another important effect to consider is a temporary increase of MBC in agricultural soils with the addition of biosolids as established by Debosz [109].

\section{Conclusions}

Biosolids proved to be a rich source of organic matter, as well as of macro- and micronutrients. The $\mathrm{pH}$ was slightly acidic, which could be favourable for agricultural soils with alkalinity problems. However, the electric conductivity was established as a parameter to be considered when establishing the application doses of biosolids to agricultural soils, especially those soils that present salinity or sodicity problems. In reference to the chemical-molecular composition of biosolids determined by FTIR analysis, it was concluded that biosolids can provide molecules, functional groups or chemically similar compounds, independent of the time in which these biosolids are generated, minimising the problem of their variability, which is a problem presented if they are used as an organic amendment to soils in the short- and long-term. With respect to biological properties, it was established that biosolids present an active microbial biomass that when applied in agricultural soils can present positive synergies with microorganisms present in soils and positively impact the mineralisation processes of $C$ and $\mathrm{N}$ sources over time. This was supported by the presence of various enzymatic activities in the biosolids evaluated over time. On the other hand, with respect to microbial diversity in the biosolids evaluated, it was concluded that this was stable or similar throughout the year, reflected in the Shannon index obtained. This stability denoted a "uniformity" that translates, in the ecological context, into a richness and relative abundance of microbial species present in biosolids and desired in complex ecosystems such as soils. Moreover, the biosolids presented a mean functional enzymatic diversity determined by SEI, concluding that microbial biomass and its enzymatic activities were active with high potential to influence processes related to the mineralisation of organic matter and the recycling of nutrients when the biosolids were applied to soils. Finally, in reference to the established correlations of physicochemical parameters with biological parameters measured over time, it is concluded that microbial biomass carbon, microbial biomass nitrogen, urease activity, metabolic coefficient, specific hydrolytic activity, $\mathrm{C}_{\text {mic }} / \mathrm{N}_{\text {mic }}$ ratio and synthetic enzymatic index are parameters that could be used as indicators of biological quality and functionality of biosolids before being used as organic amendments or fertilisers, especially for soils with agricultural activity.

Author Contributions: All authors contributed to the intellectual input and provided assistance in the study. Conceptualization, M.d.R.M.-H. and E.C.-B.; methodology, E.C.-B., M.d.R.M.-H., M.d.l.L.X.N.-R. and J.L.Á.-T.; software, M.d.R.M.-H.; validation, E.C.-B., L.G.-C., A.B.-N., and J.L.Á.-T.; formal analysis, E.C.-B. and M.d.R.M.-H.; investigation, M.d.R.M.-H. and M.S.H.; resources, M.d.I.L.X.N.-R. and M.S.-H.; data curation, M.d.R.M.-H. and M.d.l.L.X.N.-R.; writing_original draft preparation, M.d.R.M.-H.; writing-review and editing, E.C.-B. and M.d.R.M.-H., visualization, M.d.R.M.-H.; supervision, E.C.-B.; project administration, E.C.-B.; funding acquisition, E.C.-B. All authors have read and agreed to the published version of the manuscript.

Funding: This research was funded by Consejo Nacional de Ciencia y Tecnología (CONACYT)-Secretaría de Educación Pública (SEP) and Tecnológico Nacional de México/IT de Celaya, Gto., Mexico. SEP-CONACYT Project, grant numbers CB-2014-01 No. 236674 and No. 212522. Tecnológico Nacional de México/IT de Celaya Project, grant number 5569.19-P. The APC was funded by SEP-CONACYT Project, No. 236674.

Acknowledgments: To Municipal Drinking Water and Sewerage Board of the Municipality of Celaya, Guanajuato (JUMAPA). Special acknowledgements to the master's in engineering Patricia Adriana Estrada Orozco, manager of the sanitation area of JUMAPA, and to environmental engineering master José Luis Álvarez Trejo, manager of administrative and operation of the wastewater treatment plant (WWTP) of Celaya, Gto., for the administrative-technical management facilities in obtaining the urban biosolids used for the present investigation. 
Conflicts of Interest: The authors declare no conflict of interest.

\section{References}

1. De Melo, J.J.; Camara, A.S. Models for the optimization of regional wastewater treatment systems. Eur. J. Oper. Res. 1994, 73, 1-16. [CrossRef]

2. Wang, Q.; Wei, W.; Gong, Y.; Yu, Q.; Li, Q.; Sun, J.; Yuan, Z. Technologies for reducing sludge production in wastewater treatment plants: State of the art. Sci. Total Environ. 2017, 587, 510-521. [CrossRef]

3. Rodríguez, N.H.; Granados, R.J.; Blanco-Varela, M.T.; Cortina, J.L.; Martínez-Ramírez, S.; Marsal, M.; Guillem, M.; Puig, J.; Fos, C.; Larrotcha, E.; et al. Evaluation of a lime-mediated sewage sludge stabilisation process. Product characterisation and technological validation for its use in the cement industry. Waste Manag. 2012, 32, 550-560. [CrossRef] [PubMed]

4. Wei, Y.; Van Houten, R.T.; Borger, A.R.; Eikelboom, D.H.; Fan, Y. Minimization of excess sludge production for biological wastewater treatment. Water Res. 2003, 37, 4453-4467. [CrossRef]

5. Reungoat, J.; Escher, B.I.; Macova, M.; Argaud, F.X.; Gernjak, W.; Keller, J. Ozonation and biological activated carbon filtration of wastewater treatment plant effluents. Water Res. 2012, 46, 863-872. [CrossRef]

6. Pronk, M.; De Kreuk, M.K.; De Bruin, B.; Kamminga, P.; Kleerebezem, R.V.; Van Loosdrecht, M.C.M. Full scale performance of the aerobic granular sludge process for sewage treatment. Water Res. 2015, 84, 207-217. [CrossRef]

7. Fytili, D.; Zabaniotou, A. Utilization of sewage sludge in EU application of old and new methods-A review. Renew. Sustain. Energy Rev. 2008, 12, 116-140. [CrossRef]

8. Samaras, P.; Papadimitriou, C.A.; Haritou, I.; Zouboulis, A.I. Investigation of sewage sludge stabilization potential by the addition of fly ash and lime. J. Hazard. Mater. 2008, 154, 1052-1059. [CrossRef]

9. Kazimierczak, M. Sewage sludge stabilization indicators in aerobic digestion-a review. Annals of Warsaw University of Life Sciences-SGGW. Land Reclam. 2012, 44, 101-109. [CrossRef]

10. Conagua. Inventario Nacional de Plantas Municipales de Potabilización y de Tratamiento de Aguas Residuales en Operación; Comisión Nacional del Agua/Secretaría de Medio Ambiente y Recursos Naturales: Ciudad de México, México, 2016; 308p, Available online: https://agua.org.mx/biblioteca/inventario-plantaspotabilizadoras-municipales-2016/ (accessed on 14 November 2019).

11. Matos, A.T.; Diniz, I.C.; Matos, M.P.; Borges, A.C.; Pereira, A.A. Degradation rate of anaerobically digested sewage sludge in soil. J. Water Sanit. Hyg. Dev. 2018, 8, 17-26. [CrossRef]

12. Zhang, Q.; Hu, J.; Lee, D.J.; Chang, Y.; Lee, Y.J. Sludge treatment: Current research trends. Bioresour. Technol. 2017, 243, 1159-1172. [CrossRef] [PubMed]

13. Paramashivam, D.; Dickinson, N.M.; Clough, T.J.; Horswell, J.; Robinson, B.H. Potential environmental benefits from blending biosolids with other organic amendments before application to land. J. Environ. Qual. 2017, 46, 481-489. [CrossRef] [PubMed]

14. Wang, H.; Brown, S.L.; Magesan, G.N.; Slade, A.H.; Quintern, M.; Clinton, P.W.; Payn, T.W. Technological options for the management of biosolids. Environ. Sci. Pollut. Res. 2008, 15, 308-317. [CrossRef] [PubMed]

15. Nicholson, F.; Bhogal, A.; Taylor, M.; McGrath, S.; Withers, P. Long-term Effects of Biosolids on Soil Quality and Fertility. Soil Sci. 2018, 183, 89-98. [CrossRef]

16. Obrador, A.; Rico, M.I.; Mingot, J.I.; Alvarez, J.M. Metal mobility and potential bioavailability in organic matter-rich soil-sludge mixtures: Effect of soil type and contact time. Sci. Total Environ. 1997, 206, 117-126. [CrossRef]

17. Alvarez, E.A.; Mochon, M.C.; Sánchez, J.J.; Rodríguez, M.T. Heavy metal extractable forms in sludge from wastewater treatment plants. Chemosphere 2002, 47, 765-775. [CrossRef]

18. Usman, K.; Khan, S.; Ghulam, S.; Khan, M.U.; Khan, N.; Khan, M.A.; Khalil, S.K. Sewage sludge: An important biological resource for sustainable agriculture and its environmental implications. Am. J. Plant Sci. 2012, 3, 1708. [CrossRef]

19. Sharma, B.; Sarkar, A.; Singh, P.; Singh, R.P. Agricultural utilization of biosolids: A review on potential effects on soil and plant grown. Waste Manag. 2017, 64, 117-132. [CrossRef]

20. Pepper, I.L.; Brooks, J.P.; Gerba, C.P. Land Application of Organic Residuals: Municipal Biosolids and Animal Manures. In Environmental and Pollution Science, 3rd ed.; Brusseau, M.L., Pepper, I.L., Gerba, C.P., Eds.; Academic Press, Elsevier: London, UK, 2019; Part III; pp. 419-434. [CrossRef] 
21. Secretaría del Medio Ambiente y Recursos Naturales (Semarnat). Norma Oficial Mexicana NOM-004-SEMARNAT-2002. Protección Ambiental. Lodos y Biosólidos. Especificaciones y Límites Máximos Permisibles de Contaminantes Para su Aprovechamiento y Disposición Final. 2002. Diario Oficial de la Federación, México. 15 August 2003. Available online: http://biblioteca.semarnat.gob.mx/janium/Documentos/ Ciga/libros2009/DO2251.pdf (accessed on 8 January 2020).

22. Environmental Protection Agency (EPA). Federal Register. Title 40-Protection of Environment: Part 503-Standards for the Use or Disposal of Sewage Sludge; Environmental Protection Agency: Washington, DC, USA, 2002.

23. European Economic Community (ECC). Directiva 86/278/CEE de 12 de junio de 1986, relativa a la protección del medio ambiente y, en particular, de los suelos, en la utilización de lodos de depuradora en agricultura (86/278/CEE). Diario Oficial de las Comunidades Europeas. 1986. Available online: https://eur-lex.europa.eu/ legal-content/ES/TXT/PDF/?uri=CELEX:31986L0278\&from=ES (accessed on 8 January 2020).

24. Anderson, J.P.E.; Domsch, K.H. Quantities of plant nutrients in the microbial biomass of selected soils. Soil Sci. 1980, 130, 211-216. [CrossRef]

25. Kandeler, E.; Gerber, H. Short-term assay of soil urease activity using colorimetric determination of ammonium. Biol. Fertil. Soils 1988, 6, 68-72. [CrossRef]

26. Sparling, G.P.; West, A.W. Modifications to the fumigation extraction technique to permit simultaneous extraction and estimation of soil microbial C and N. Commun Soil Sci Plant Anal. 1988, 19, 327-344. [CrossRef]

27. Anderson, T.H.; Domsch, K.H. Application of eco-physiological quotients ( $\mathrm{qCO}_{2}$ and $\mathrm{qD}$ ) on microbial biomasses from soils of different cropping histories. Soil Biol. Biochem. 1990, 22, 251-255. [CrossRef]

28. Von Mersi, W.; Schinner, F. An improved and accurate method for determining the dehydrogenase activity of soils with iodonitrotetrazolium chloride. Biol. Fertil. Soils 1991, 11, 216-220. [CrossRef]

29. Johnston, C.T.; Aochi, Y. Fourier transform infrared and raman spectroscopy. In Methods of Soil Analysis; Bartels, J.M., Bigham, J.M., Eds.; Soil Science Society of America, American Society of Agronomy: Madison, WI, USA, 1996; pp. 269-321. [CrossRef]

30. Perucci, P.; Dumontet, S.; Bufo, S.A.; Mazzatura, A.; Casucci, C. Effects of organic amendment and herbicide treatment on soil microbial biomass. Biol. Fertil. Soils 2000, 32, 17-23. [CrossRef]

31. Dumontet, S.; Mazzatura, A.; Casucci, C.; Perucci, P. Effectiveness of microbial indexes in discriminating interactive effects of tillage and crop rotations in a Vertic Ustorthens. Biol. Fertil. Soils 2001, 34, 411-416. [CrossRef]

32. Green, V.S.; Stott, D.E.; Diack, M. Assay for fluorescein diacetate hydrolytic activity: Optimization for soil samples. Soil Biol. Biochem. 2006, 38, 693-701. [CrossRef]

33. Martínez, E.J.; Fierro, J.; Sánchez, M.E.; Gómez, X. Anaerobic co-digestion of FOG and sewage sludge: Study of the process by Fourier transform infrared spectroscopy. Int. Biodeterior. Biodegrad. 2012, 75, 1-6. [CrossRef]

34. Tiquia, S.M. Evolution of extracellular enzyme activities during manure composting. J. Appl. Microbiol. 2002, 92, 764-775. [CrossRef]

35. Baldrian, P.; Voříšková, J.; Dobiášová, P.; Merhautová, V.; Lisá, L.; Valášková, V. Production of extracellular enzymes and degradation of biopolymers by saprotrophic microfungi from the upper layers of forest soil. Plant Soil 2011, 338, 111-125. [CrossRef]

36. Boluda, R.; Roca-Pérez, L.; Iranzo, M.; Gil, C.; Mormeneo, S. Determination of enzymatic activities using a miniaturized system as a rapid method to assess soil quality. Eur. J. Soil Sci. 2014, 65, 286-294. [CrossRef]

37. Shemekite, F.; Gómez-Brandón, M.; Franke-Whittle, I.H.; Praehauser, B.; Insam, H.; Assefa, F. Coffee husk composting: An investigation of the process using molecular and non-molecular tools. Waste Manag. 2014, 34, 642-652. [CrossRef]

38. Martinez, D.; Molina, M.J.; Sanchez, J.; Moscatelli, M.C.; Marinari, S. API ZYM assay to evaluate enzyme fingerprinting and microbial functional diversity in relation to soil processes. Biol. Fertil. Soils 2016, 52, 77-89. [CrossRef]

39. Patel, D.; Gismondi, R.; Alsaffar, A.; Tiquia-Arashiro, S.M. Applicability of API ZYM to capture seasonal and spatial variabilities in lake and river sediments. Environ. Technol. 2019, 40, 3227-3239. [CrossRef] [PubMed]

40. Wolińska, A.; Frąc, M.; Oszust, K.; Szafranek-Nakonieczna, A.; Zielenkiewicz, U.L.; Stępniewska, Z. Microbial biodiversity of meadows under different modes of land use: Catabolic and genetic fingerprinting. World J. Microbiol. Biotechnol. 2017, 33, 154. [CrossRef] 
41. Environmental Protection Agency (EPA). A Guide to the Biosolids Risk Assessments for the EPA Part 503 Rule; Tech. Rep. EPA/832-B-93-005; Office of Wastewater Management: Washington, DC, USA, 1995.

42. Lu, Q.; He, Z.L.; Stoffella, P.J. Land application of biosolids in the USA: A review. Appl. Environ. Soil Sci. 2012, 2012, 201462. [CrossRef]

43. Coello-Oviedo, M.C.; Barragán-Sánchez, J.B.; Quiroga-Alonso, J.Q. Enzymatic estimation of biosolids stability in aerobic digestion systems. Enzyme Microb. Technol. 2005, 36, 191-197. [CrossRef]

44. Boczar, B.A.; Begley, W.M.; Larson, R.J. Characterization of enzyme activity in activated sludge using rapid analyses for specific hydrolases. Water Environ. Res. 1992, 64, 792-797. [CrossRef]

45. Ho, C.P.; Yuan, S.T.; Jien, S.H.; Hseu, Z.Y. Elucidating the process of co-composting of biosolids and spent activated clay. Bioresour. Technol. 2010, 101, 8280-8286. [CrossRef]

46. Tian, G.; Franzluebbers, A.J.; Granato, T.C.; Cox, A.E.; O'connor, C. Stability of soil organic matter under long-term biosolids application. Appl. Soil Ecol. 2013, 64, 223-227. [CrossRef]

47. Thomas, G.W. Soil pH and Soil Acidity. In Methods of Soil Analysis Part 3-Chemical Methods; Sparks, D.L., Page, A.L., Helmke, P.A., Loeppert, R.H., Eds.; Soil Science Society of America: Madison, WI, USA, 1996; pp. 475-490. [CrossRef]

48. Hendrickx, J.M.H.; Das, B.; Corwin, D.L.; Wraith, J.M.; Kachanoski, R.G. Relationship between soil water solute concentration and apparent soil electrical conductivity. In Methods of Soil Analysis: Part 4. Physical Methods; Dane, J.H., Topp, G.C., Eds.; Soil Science Society of America: Madison, WI, USA, 2002; pp. 1275-1282. [CrossRef]

49. Walkley, A.; Black, C.A. An examination of different methods for determining soil organic matter and a proposed modification of the chromic acid titration method. Soil Sci. 1934, 37, 29-38. [CrossRef]

50. Alef, K.; Nannipieri, P. Methods in Applied Soil Microbiology and Biochemistry; Academic Press: London, UK, 1995; pp. 60-61. [CrossRef]

51. Bremner, J.M. Nitrogen-Total. In Methods of Soil Analysis Part 3-Chemical Methods; Sparks, D.L., Page, A.L., Helmke, P.A., Loeppert, R.H., Eds.; Soil Science Society of America: Madison, WI, USA, 1996; pp. 1085-1121. [CrossRef]

52. US-EPA Method 3051A. Microwave Assisted Acid Digestion of Sediment, Sludges, Soils, and Oils; United States Environmental Protection Agency: Washington, DC, USA, 2007. Available online: https://www.epa.gov/ sites/production/files/2015-12/documents/3051a.pdf (accessed on 14 November 2019).

53. Link, D.D.; Walter, P.J.; Kingston, H.M. Development and validation of the new EPA microwave-assisted leach method 3051A. Environ. Sci. Technol. 1998, 32, 3628-3632. [CrossRef]

54. Bettinelli, M.; Baroni, U. A microwave oven digestion method for the determination of metals in sewage sludges by ICP-AES and GFAAS. Int. J. Environ. Anal. Chem. 1991, 43, 33-40. [CrossRef]

55. Sparling, G.P.; Williams, B.L. Microbial biomass in organic soils: Estimation of biomass C, and effect of glucose or cellulose amendments on the amounts of $\mathrm{N}$ and P released by fumigation. Soil Biol. Biochem. 1986, 18, 507-513. [CrossRef]

56. Barragán-Sánchez, J.; Quiroga-Alonso, J.M.; Coello-Oviedo, M.D. Use of microbial activity parameters for determination of a biosolid stability index. Bioresour. Technol. 2006, 97, 562-568. [CrossRef]

57. Anderson, J.P. Soil respiration. In Methods of Soil Analysis Part 2-Chemical and Microbiological Properties; Page, L., Ed.; Soil Science Society of America: Madison, WI, USA, 1982; pp. 831-871. [CrossRef]

58. API ZYM 25200. Sistema de investigación de actividades enzimáticas; 07883F-es-2014/01; bioMérieux SA: Marcy-l'Étoile, France, 2014; p. 5.

59. Kennedy, A.C.; Smith, K.L. Soil microbial diversity and the sustainability of agricultural soils. Plant Soil 1995, 170, 75-86. [CrossRef]

60. Minitab, Inc. Minitab Version 18; Minitab, Inc.: State College, PA, USA, 2018.

61. Withers, P.J.A.; Flynn, N.J.; Warren, G.P.; Taylor, M.; Chambers, B.J. Sustainable management of biosolid phosphorus: A field study. Soil Use Manag. 2016, 32, 54-63. [CrossRef]

62. Torri, S.I.; Correa, R.S.; Renella, G. Biosolid application to agricultural land-A contribution to global phosphorus recycle: A review. Pedosphere 2017, 27, 1-16. [CrossRef]

63. Sánchez-Monedero, M.A.; Mondini, C.; De Nobili, M.; Leita, L.; Roig, A. Land application of biosolids. Soil response to different stabilization degree of the treated organic matter. Waste Manag. 2004, 24, 325-332. [CrossRef] 
64. Torres, D.; Mendoza, B.; Meru Marco, L.; Gómez, C. Riesgos de salinización y sodificación por el uso de abonos orgánicos en la depresión de Quíbor-Venezuela. Multiciencias 2016, 16, 133-142. Available online: https://www.redalyc.org/articulo.oa?id=90452745003 (accessed on 15 July 2019).

65. Cytryn, E.; Kautsky, L.; Ofek, M.; Mandelbaum, R.T.; Minz, D. Short-term structure and functional changes in bacterial community composition following amendment with biosolids compost. Appl. Soil Ecol. 2011, 48, 160-167. [CrossRef]

66. Sciubba, L.; Cavani, L.; Negroni, A.; Zanaroli, G.; Fava, F.; Ciavatta, C.; Marzadori, C. Changes in the functional properties of a sandy loam soil amended with biosolids at different application rates. Geoderma 2014, 221, 40-49. [CrossRef]

67. Flores-Margez, J.P.; Corral-Díaz, B.; Sapien-Mediano, G. Mineralización de nitrógeno de biosólidos estabilizados con cal en suelos agrícolas. Terra Latinoam. 2007, 25, 409-417. Available online: http://portal.amelica.org/ameli/jatsRepo/57315558009 (accessed on 8 January 2020).

68. Potisek-Talavera, M.D.C.; Figueroa-Viramontes, U.; González-Cervantes, G.; Jasso-Ibarra, R.; Orona-Castillo, I. Aplicación de biosólidos al suelo y su efecto sobre contenido de materia orgánica y nutrimentos. Terra Latinoam. 2010, 28, 327-333. Available online: http://www.scielo.org.mx/pdf/tl/v28n4/v28n4a4.pdf (accessed on 8 January 2020).

69. González-Flores, E.; Ramos-Barragán, J.E.; Tornero-Campante, M.A.; Murillo-Murillo, M. Evaluación de dosis de biosólidos urbanos en maíz bajo condiciones de invernadero. Rev. Mex. Cienc. Agríc. 2017, 8, 119-132. Available online: http://www.scielo.org.mx/pdf/remexca/v8n1/2007-0934-remexca-8-01-119-en.pdf (accessed on 20 December 2019).

70. Singh, R.P.; Agrawal, M. Effect of different sewage sludge applications on growth and yield of Vigna radiata L. field crop: Metal uptake by plant. Ecol. Eng. 2010, 36, 969-972. [CrossRef]

71. Xue, D.; Huang, X. The impact of sewage sludge compost on tree peony growth and soil microbiological, and biochemical properties. Chemosphere 2013, 93, 583-589. [CrossRef]

72. Lloret, E.; Pascual, J.A.; Brodie, E.L.; Bouskill, N.J.; Insam, H.; Juárez, M.F.D.; Goberna, M. Sewage sludge addition modifies soil microbial communities and plant performance depending on the sludge stabilization process. Appl. Soil Ecol. 2016, 101, 37-46. [CrossRef]

73. United States Salinity Laboratory Staff (USSLS). Diagnosis and Improvement of Saline and Alkali Soils; United States Department of Agriculture and Government Printing Office: Washington, DC, USA, 1954. Available online: https://www.ars.usda.gov/ARSUserFiles/20360500/hb60_pdf/hb60complete.pdf (accessed on 14 November 2019).

74. Pérez-Sanz, A.; Lucena, J.J.; Graham, M.C. Characterization of Fe-humic complexes in an Fe-enriched biosolid by-product of water treatment. Chemosphere 2006, 65, 2045-2053. [CrossRef]

75. Rowell, D.M.; Prescott, C.E.; Preston, C.M. Decomposition and nitrogen mineralization from biosolids and other organic materials. J. Environ. Qual. 2001, 30, 1401-1410. [CrossRef]

76. Gilmour, J.T.; Cogger, C.G.; Jacobs, L.W.; Evanylo, G.K.; Sullivan, D.M. Decomposition and plant-available nitrogen in biosolids. J. Environ. Qual. 2003, 32, 1498-1507. [CrossRef]

77. Rigby, H.; Clarke, B.O.; Pritchard, D.L.; Meehan, B.; Beshah, F.; Smith, S.R.; Porter, N.A. A critical review of nitrogen mineralization in biosolids-amended soil, the associated fertilizer value for crop production and potential for emissions to the environment. Sci. Total Environ. 2016, 541, 1310-1338. [CrossRef] [PubMed]

78. Jin, V.L.; Johnson, M.V.V.; Haney, R.L.; Arnold, J.G. Potential carbon and nitrogen mineralization in soils from a perennial forage production system amended with class B biosolids. Agric. Ecosyst. Environ. 2011, 141, 461-465. [CrossRef]

79. Hseu, Z.Y.; Huang, C.C. Nitrogen mineralization potentials in three tropical soils treated with biosolids. Chemosphere 2005, 59, 447-454. [CrossRef] [PubMed]

80. Brady, N.C.; Weil, R.R. The Nature and Properties of Soils, 14th ed.; Prentice Hall: Upper Saddle River, NJ, USA, 2008; pp. 100-109.

81. Lü, F.; Shao, L.M.; Zhang, H.; Fu, W.D.; Feng, S.J.; Zhan, L.T.; Chen, Y.M.; He, P.J. Application of advanced techniques for the assessment of bio-stability of biowaste-derived residues: A minireview. Bioresour. Technol. 2018, 248, 122-133. [CrossRef] [PubMed] 
82. Sullivan, D.M.; Cogger, C.G.; Bary, A.I. Fertilising with Biosolids; A Pacific North West Extension Publication, Oregon State University: Corvallis, OR, USA; Washington State University: Pullman, WA, USA; University of Idaho: Moscow, ID, USA, 2015; Available online: https://catalog.extension.oregonstate.edu/sites/catalog/ files/project/pdf/pnw508_0.pdf (accessed on 17 December 2019).

83. Sigua, G.C. Recycling biosolids and lake-dredged materials to pasture-based animal agriculture: Alternative nutrient sources for forage productivity and sustainability. A review. Agron. Sustain. Dev. 2009, 29, 143-160. [CrossRef]

84. Zhang, M.; Heaney, D.; Henriquez, B.; Solberg, E.; Bittner, E. A four-year study on influence of biosolids/MSW cocompost application in less productive soils in Alberta: Nutrient dynamics. Compost Sci. Util. 2006, 14, 68-80. [CrossRef]

85. Kokkora, M.I.; Antille, D.L.; Tyrrel, S.F. Considerations for recycling of compost and biosolids in agricultural soil. In Soil Engineering; Dedousis, A.P., Bartzanas, T., Eds.; Springer: Berlin/Heidelberg, Germany, 2010; Volume 20, pp. 195-215. [CrossRef]

86. Bedoya-Urrego, K.; Acevedo-Ruíz, J.M.; Peláez-Jaramillo, C.A.; Agudelo-López, S.D.P. Caracterización de biosólidos generados en la planta de tratamiento de agua residual San Fernando, Itagüí (Antioquia, Colombia). Rev. Salud Pública 2013, 15, 778-790. Available online: https://www.scielosp.org/scielo.php? script=sci_arttext\&pid=S0124-00642013000500013 (accessed on 20 April 2019).

87. Dede, G.; Özdemir, S.; Dede, Ö.H.; Altundağ, H.; Dündar, M.Ş.; Kızıloğlu, F.T. Effects of biosolid application on soil properties and kiwi fruit nutrient composition on high-pH soil. Int. J. Environ. Sci. Technol. 2017, 14, 1451-1458. [CrossRef]

88. Burducea, M.; Zheljazkov, V.D.; Lobiuc, A.; Pintilie, C.A.; Virgolici, M.; Silion, M.; Asandulesa, M.; Burducea, I.; Zamfirache, M.M. Biosolids application improves mineral composition and phenolic profile of basil cultivated on eroded soil. Sci. Hortic. 2019, 249, 407-418. [CrossRef]

89. Wang, K.; Li, W.; Gong, X.; Li, Y.; Wu, C.; Ren, N. Spectral study of dissolved organic matter in biosolid during the composting process using inorganic bulking agent: UV-vis, GPC, FTIR and EEM. Int. Biodeterior. Biodegrad. 2013, 85, 617-623. [CrossRef]

90. Zhou, Y.; Selvam, A.; Wong, J.W. Evaluation of humic substances during co-composting of food waste, sawdust and Chinese medicinal herbal residues. Bioresour. Technol. 2014, 168, 229-234. [CrossRef]

91. Zhang, J.; Lü, F.; Shao, L.; He, P. The use of biochar-amended composting to improve the humification and degradation of sewage sludge. Bioresour. Technol. 2014, 168, 252-258. [CrossRef] [PubMed]

92. Soobhany, N.; Gunasee, S.; Rago, Y.P.; Joyram, H.; Raghoo, P.; Mohee, R.; Garg, V.K. Spectroscopic, thermogravimetric and structural characterization analyses for comparing Municipal Solid Waste composts and vermicomposts stability and maturity. Bioresour. Technol. 2017, 236, 11-19. [CrossRef]

93. El Fels, L.; Zamama, M.; El Asli, A.; Hafidi, M. Assessment of biotransformation of organic matter during co-composting of sewage sludge-lignocelullosic waste by chemical, FTIR analyses, and phytotoxicity tests. Int. Biodeterior. Biodegrad. 2014, 87, 128-137. [CrossRef]

94. Tandy, S.; Healey, J.R.; Nason, M.A.; Williamson, J.C.; Jones, D.L.; Thain, S.C. FT-IR as an alternative method for measuring chemical properties during composting. Bioresour. Technol. 2010, 101, 5431-5436. [CrossRef] [PubMed]

95. Aksoy, C.; Severcan, F. Role of vibrational spectroscopy in stem cell research. J. Spectrosc. 2012, 27, 167-184. [CrossRef]

96. Droussi, Z.; D’orazio, V.; Provenzano, M.R.; Hafidi, M.; Ouatmane, A. Study of the biodegradation and transformation of olive-mill residues during composting using FTIR spectroscopy and differential scanning calorimetry. J. Hazard. Mater. 2009, 164, 1281-1285. [CrossRef] [PubMed]

97. Bastida, F.; Zsolnay, A.; Hernández, T.; García, C. Past, present and future of soil quality indices: A biological perspective. Geoderma 2008, 147, 159-171. [CrossRef]

98. Paz-Ferreiro, J.; Fu, S. Biological indices for soil quality evaluation: Perspectives and limitations. Land Degrad. Dev. 2016, 27, 14-25. [CrossRef]

99. Joniec, J. Enzymatic activity as an indicator of regeneration processes in degraded soil reclaimed with various types of waste. Int. J. Environ. Sci. Technol. 2018, 15, 2241-2252. [CrossRef]

100. Wardle, D.A. A comparative assessment of factors which influence microbial biomass carbon and nitrogen levels in soil. Biol. Rev. 1992, 67, 321-358. [CrossRef] 
101. Rinklebe, J.; Langer, U. Relationship between soil microbial biomass determined by SIR and PLFA analysis in floodplain soils. J. Soil Sediments 2010, 10, 4-8. [CrossRef]

102. Anderson, T.H.; Domsch, K.H. Soil microbial biomass: The eco-physiological approach. Soil Biol. Biochem. 2010, 42, 2039-2043. [CrossRef]

103. Rittmann, B.E.; McCarty, P.L. Environmental Biotechnology: Principles and Applications; McGraw-Hill Series in Water Resources and Environmental Engineering; McGraw-Hill: Boston, MA, USA, 2001.

104. Nayak, B.S.; Levine, A.D.; Cardoso, A.; Harwood, V.J. Microbial population dynamics in laboratory-scale solid waste bioreactors in the presence or absence of biosolids. J. Appl. Microbiol. 2009, 107, 1330-1339. [CrossRef]

105. Sciubba, L.; Cavani, L.; Marzadori, C.; Ciavatta, C. Effect of biosolids from municipal sewage sludge composted with rice husk on soil functionality. Biol. Fertil. Soils 2013, 49, 597-608. [CrossRef]

106. Moore, J.M.; Klose, S.; Tabatabai, M.A. Soil microbial biomass carbon and nitrogen as affected by cropping systems. Biol. Fertil. Soils 2000, 31, 200-210. [CrossRef]

107. Li, F.M.; Song, Q.H.; Jjemba, P.K.; Shi, Y.C. Dynamics of soil microbial biomass C and soil fertility in cropland mulched with plastic film in a semiarid agro-ecosystem. Soil Biol. Biochem. 2004, 36, 1893-1902. [CrossRef]

108. Fernandes, S.A.P.; Bettiol, W.; Cerri, C.C. Effect of sewage sludge on microbial biomass, basal respiration, metabolic quotient and soil enzymatic activity. Appl. Soil Ecol. 2005, 30, 65-77. [CrossRef]

109. Debosz, K.; Petersen, S.O.; Kure, L.K.; Ambus, P. Evaluating effects of sewage sludge and household compost on soil physical, chemical and microbiological properties. Appl. Soil Ecol. 2002, 19, 237-248. [CrossRef]

110. Masunga, R.H.; Uzokwe, V.N.; Mlay, P.D.; Odeh, I.; Singh, A.; Buchan, D.; De Neve, S. Nitrogen mineralization dynamics of different valuable organic amendments commonly used in agriculture. Appl. Soil Ecol. 2016, 101, 185-193. [CrossRef]

111. Molina-Herrera, S.; Romanyà, J. Synergistic and antagonistic interactions among organic amendments of contrasted stability, nutrient availability and soil organic matter in the regulation of $\mathrm{C}$ mineralisation. Eur. J. Soil Biol. 2015, 70, 118-125. [CrossRef]

112. Servicio Meteorológico Nacional (SMN). Resúmenes Mensuales de Temperaturas y Lluvia; Servicio Meteorológico Nacional: Ciudad de México, México, 2019. Available online: https://smn.conagua.gob.mx (accessed on 18 August 2019).

113. Sautour, M.; Dantigny, P.; Divies, C.; Bensoussan, M. A temperature-type model for describing the relationship between fungal growth and water activity. Int. J. Food Microbiol. 2001, 67, 63-69. [CrossRef]

114. Ratkowsky, D.A.; Lowry, R.K.; McMeekin, T.A.; Stokes, A.N.; Chandler, R.E. Model for bacterial culture growth rate throughout the entire biokinetic temperature range. J. Bacteriol. 1983, 154, 1222-1226. [CrossRef] [PubMed]

115. Nannipieri, P.; Trasar-Cepeda, C.; Dick, R.P. Soil enzyme activity: A brief history and biochemistry as a basis for appropriate interpretations and meta-analysis. Biol. Fertil. Soils 2018, 54, 11-19. [CrossRef]

116. Wolińska, A.; Bennicelli, R.P. Dehydrogenase activity response to soil reoxidation process described as varied conditions of water potential, air porosity and oxygen availability. Pol. J. Environ. Stud. 2010, 19, 651-657.

117. Quilchano, C.; Marañón, T. Dehydrogenase activity in Mediterranean forest soils. Biol. Fertil. Soils 2002, 35 , 102-107. [CrossRef]

118. Kumar, S.; Chaudhuri, S.; Maiti, S.K. Soil dehydrogenase enzyme activity in natural and mine soil-A review. Middle East J. Sci. Res. 2013, 13, 898-906. [CrossRef]

119. Wolińska, A.; Rekosz-Burlaga, H.; Goryluk-Salmonowicz, A.; Błaszczyk, M.; Stępniewska, Z. Bacterial Abundance and Dehydrogenase Activity in Selected Agricultural Soils from Lublin Region. Pol. J. Environ. Stud. 2015, 24, 2677-2682. [CrossRef]

120. Pascual, J.A.; Garcia, C.; Hernandez, T.; Moreno, J.L.; Ros, M. Soil microbial activity as a biomarker of degradation and remediation processes. Soil Biol. Biochem. 2000, 32, 1877-1883. [CrossRef]

121. Paz-Ferreiro, J.; Gascó, G.; Gutiérrez, B.; Méndez, A. Soil biochemical activities and the geometric mean of enzyme activities after application of sewage sludge and sewage sludge biochar to soil. Biol. Fertil. Soils 2012, 48, 511-517. [CrossRef]

122. Roig, N.; Sierra, J.; Martí, E.; Nadal, M.; Schuhmacher, M.; Domingo, J.L. Long-term amendment of Spanish soils with sewage sludge: Effects on soil functioning. Agric. Ecosyst. Environ. 2012, 158, 41-48. [CrossRef] 
123. Wijesekara, H.; Bolan, N.S.; Thangavel, R.; Seshadri, B.; Surapaneni, A.; Saint, C.; Hetherington, C.; Matthews, P.; Vithanage, M. The impact of biosolids application on organic carbon and carbon dioxide fluxes in soil. Chemosphere 2017, 189, 565-573. [CrossRef] [PubMed]

124. Gajda, A.M.; Przewłoka, B.; Gawryjołek, K. Changes in soil quality associated with tillage system applied. Int. Agrophys. 2013, 27, 133-141. [CrossRef]

125. Muscolo, A.; Settineri, G.; Attinà, E. Early warning indicators of changes in soil ecosystem functioning. Ecol. Ind. 2015, 48, 542-549. [CrossRef]

126. Sánchez-Monedero, M.A.; Mondini, C.; Cayuela, M.L.; Roig, A.; Contin, M.; De Nobili, M. Fluorescein diacetate hydrolysis, respiration and microbial biomass in freshly amended soils. Biol. Fertil. Soils 2008, 44, 885-890. [CrossRef]

127. Carlson, J.; Saxena, J.; Basta, N.; Hundal, L.; Busalacchi, D.; Dick, R.P. Application of organic amendments to restore degraded soil: Effects on soil microbial properties. Environ. Monit. Assess. 2015, 187, 109. [CrossRef] [PubMed]

128. Diacono, M.; Montemurro, F. Long-term effects of organic amendments on soil fertility. In Sustainable Agriculture; Lichtfouse, E., Hamelin, M., Navarrete, M., Debaeke, P., Eds.; Springer: Dordrecht, The Netherlands, 2011; Volume 2, pp. 761-786. [CrossRef]

129. Kizilkaya, R.; Bayrakl1, B. Effects of N-enriched sewage sludge on soil enzyme activities. Appl. Soil Ecol. 2005, 30, 192-202. [CrossRef]

130. Yakushev, A.V.; Blagodatsky, S.A.; Byzov, B.A. The effect of earthworms on the physiological state of the microbial community at vermicomposting. Microbiology 2009, 78, 510-519. [CrossRef]

131. Tian, G.; Chiu, C.Y.; Franzluebbers, A.J.; Oladeji, O.O.; Granato, T.C.; Cox, A.E. Biosolids amendment dramatically increases sequestration of crop residue-carbon in agricultural soils in western Illinois. Appl. Soil Ecol. 2015, 85, 86-93. [CrossRef]

132. Sofo, A.; Scopa, A.; Dumontet, S.; Mazzatura, A.; Pasquale, V. Toxic effects of four sulphonylureas herbicides on soil microbial biomass. J. Environ. Sci. Health Part B 2012, 47, 653-659. [CrossRef]

133. Seal, A.; Datta, A.; Saha, S.; Chatterjee, A.K.; Barik, A.K.; Bhattacharyya, S.; Levin, Y.; Nain, A.S.; Asthana, A.; Bera, R. Soil Microbial Rejuvenation through Soil Resource Recycling as a part of Sustainable Management Programme: A Case Study from Lakhipara Tea Estate, Dooars, West Bengal, India. J. Agric. Sci. Technol. 2016, 5 , 18-34. Available online: http://orgprints.org/31300/1/1248-4636-1-PB\%20\%28Lakhipara\%20Compost\%29.pdf (accessed on 20 December 2019).

134. Tian, L.; Dell, E.; Shi, W. Chemical composition of dissolved organic matter in agroecosystems: Correlations with soil enzyme activity and carbon and nitrogen mineralization. Appl. Soil Ecol. 2010, 46, 426-435. [CrossRef]

135. Tiemann, L.K.; Billings, S.A. Indirect effects of nitrogen amendments on organic substrate quality increase enzymatic activity driving decomposition in a mesic grassland. Ecosystems 2011, 14, 234-247. [CrossRef]

136. Zhao, S.; Li, K.; Zhou, W.; Qiu, S.; Huang, S.; He, P. Changes in soil microbial community, enzyme activities and organic matter fractions under long-term straw return in north-central China. Agric. Ecosyst. Environ. 2016, 216, 82-88. [CrossRef]

137. Bending, G.D.; Turner, M.K.; Jones, J.E. Interactions between crop residue and soil organic matter quality and the functional diversity of soil microbial communities. Soil Biol. Biochem. 2002, 34, 1073-1082. [CrossRef]

138. Kemmitt, S.J.; Lanyon, C.V.; Waite, I.S.; Wen, Q.; Addiscott, T.M.; Bird, N.R.; O’Donnell, A.G.; Brookes, P.C. Mineralization of native soil organic matter is not regulated by the size, activity or composition of the soil microbial biomass-A new perspective. Soil Biol. Biochem. 2008, 40, 61-73. [CrossRef]

139. Burns, R.G.; DeForest, J.L.; Marxsen, J.; Sinsabaugh, R.L.; Stromberger, M.E.; Wallenstein, M.D.; Weintraub, M.; Zoppini, A. Soil enzymes in a changing environment: Current knowledge and future directions. Soil Biol. Biochem. 2013, 58, 216-234. [CrossRef]

140. Wang, X.; Song, D.; Liang, G.; Zhang, Q.; Ai, C.; Zhou, W. Maize biochar addition rate influences soil enzyme activity and microbial community composition in a fluvo-aquic soil. Appl. Soil Ecol. 2015, 96, 265-272. [CrossRef]

141. Yeshitela, K. Effects of Anthropogenic Disturbance on the Diversity of Foliicolous Lichens in Tropical Rainforests of East Africa: Godere (Ethiopia), Budongo (Uganda) and Kakamega (Kenya). Ph.D. Thesis, Universität Koblenz-Landau, Mainz, Germany, 2008; pp. 13-14. 
142. Wang, C.; Liu, D.; Bai, E. Decreasing soil microbial diversity is associated with decreasing microbial biomass under nitrogen addition. Soil Biol. Biochem. 2018, 120, 126-133. [CrossRef]

143. Stone, M.M.; DeForest, J.L.; Plante, A.F. Changes in extracellular enzyme activity and microbial community structure with soil depth at the Luquillo Critical Zone Observatory. Soil Biol. Biochem. 2014, 75, 237-247. [CrossRef] 